\title{
The Vernacular and Latin Translations of Confucius
}

By the third quarter of the seventeenth century, the Society of Jesus directly or indirectly dominated the Dutch debate on China in print. Jesuits like Nicolas Trigault and Martino Martini provided many of the eyewitness accounts that were adopted by Dutch authors, translators, and publishers. They, in turn, constructed narratives on the Middle Kingdom that shaped and disseminated images of Chinese religion and philosophy. The Dutch did this by producing printed works of exceptional quality and by utilising their extensive networks of distribution; significantly in this respect, their content was largely free from censure by Church and State.

This proliferation of Jesuit accounts had profound implications for the religious and cultural representation of China. In fact, Jesuit publications were instrumental in making Confucius the main protagonist of Europe's interactions with Asian philosophy: simply consider the fact that 'Confucius' is the Jesuit Latinisation of the Chinese title of Kong Fuzi 孔夫子, literally 'Master Kong.' Thus, other potential representations of China, such as Buddhism and Taoism, were generally rejected as the Jesuits were of the opinion that only the ethical and social doctrine of Confucius should be complemented with the metaphysical ideas of Christianity. ${ }^{2}$

Confucius had become the focal point of the Jesuit missionary policy since they believed that China could only be converted to Christianity from within. After earlier attempts at posing as simple monks from the West, catering only to the lower classes, they began to accommodate the ruling classes who embraced Confucianism as their cultural and intellectual standard. The Jesuits also incorporated local cultural and philosophical traditions into their preaching of Christianity to justify the supposed compatibilities between Chinese and Christian concepts. ${ }^{3}$ Consequently, they tried to identify the essential

1 To quote Björn Löwendahl: 'By one of the strange ironies of history, Europe first learned of Confucius from Jesuits who had been sent out to convert the "heathen" Chinese', in Björn Löwendahl, China illustrata nova. Sino-Western relations, conceptions of China, cultural influences and the development of Sinology disclosed in Western printed Books 1477-1877 (Hua Hin: Elephant Press, 2008), p. 18.

2 Thierry Meynard, 'Beyond religious exclusivism. The Jesuit attacks against Buddhism and Xu Dashou's refutation of 1623', Journal of Jesuit Studies, 4.3 (2017), pp. 415-430.

3 Nicolas Dew, Orientalism in Louis XIV's France (Oxford: Oxford University Press, 2009), p. 211.

(C) TRUDE DIJKSTRA, 2022 | DOI:10.1163/9789004473294_005

This is an open access chapter distributed under the terms of the CC BY-NC 4.o licensede Dijkstra - 9789004473294 


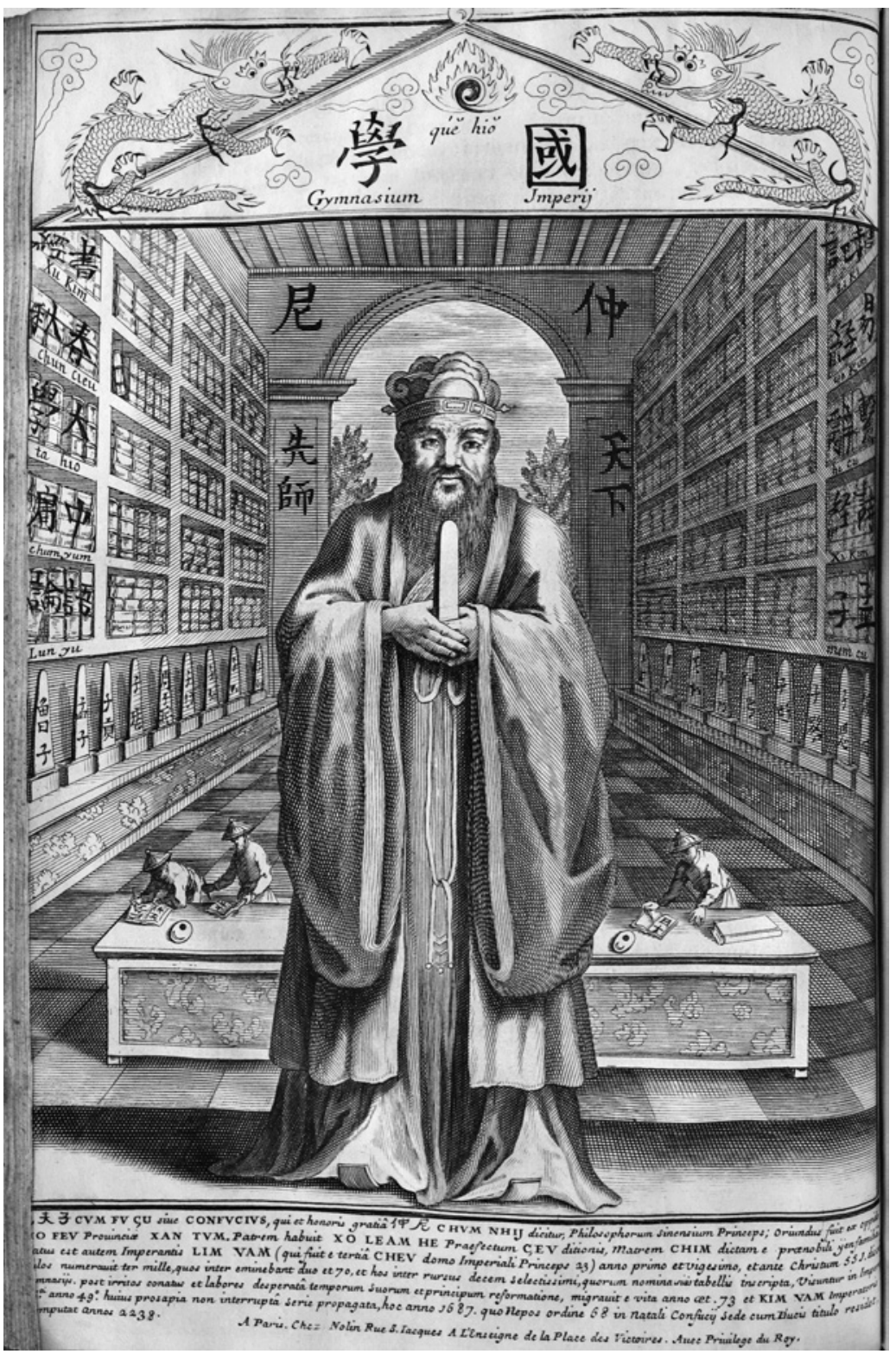

FIgUre 22 Portrait of Confucius in Philippe Couplet et al., Confucius Sinarum Philosophus (Paris: Daniel Horthemels, 1687) Allard Pierson Amsterdam (K 61-272) 
tenets that Chinese philosophy shared with Christianity, which could later serve as a base for a project of mass conversion.

To defend this unconventional approach to their European audience, the Jesuits decided to produce a publication of the main works of Confucius in Latin. This edition, Confucius Sinarum philosophus containing three of the Four Books that traditionally made up the Confucian canon, was published in Paris in 1687. Through this Jesuit translation, Confucius was (according to one scholar) the world's 'first philosopher to become famous outside his country, in other continents and civilisations.' ${ }^{4}$ Confucius's original fifth century BCE writings have not survived, only the records of his disciples have; these were compiled much later during the Han dynasty (206 ВCE-220 BCE). Many historical details about his life remain unclear and it is uncertain when, and whether, there was ever a coherent philosophical school that could be called 'Confucianism'. Modern scholarship even debates whether or not the Jesuits had 'invented' or 'manufactured' Confucianism. ${ }^{5}$

Even though Confucius Sinarum philosophus was a Jesuit venture, the involvement of various Dutch and Southern Netherlandish interlocutors makes clear that 'manufacturing Confucius' was a widespread European project. Various non-Jesuit actors participated in translating, editing, publishing, printing, explaining, and criticising the Jesuit representation of Confucius. This surrounding context had the effect of enmeshing Latin scholarship with vernacular writings, as well as integrating expertise from both Europe and Asia. The resulting 'cosmopolitan' dimension that Confucius attained was partly due to the seminal role of the Jesuits, who drew members from all over the globe. The Dutch Republic, too, featured prominently in this network, as the Jesuits needed support from Dutch intermediaries (merchants, authors, translators, illustrators, engravers, publishers, and printers) for such an unprecedented publication. By the last quarter of the seventeenth century, Confucius had become the central figure in Europe's interactions with China. Jesuit missionaries were the catalyst for the dissemination of Confucius's works, with the Southern Netherlandish Philippe Couplet (known in China as Bai Yingli 柏應理) at the helm. Their Latin translation of Confucius's works became the primary intermediary for interactions with China.

4 Kristofer Schipper, Confucius. De gesprekken (Amsterdam: Uitgeverij Augustus, 2015), pp. 13-20.

5 Rule, 'K'ung-tzu or Confucius?'; Lionel M. Jensen, Manufacturing Confucianism. Chinese traditions and universal civilization (London: Duke University Press, 1997); Standaert, "The Jesuits did NOT manufacture "Confucianism", pp. 129-169. 
This chapter examines Latin and vernacular translations of Confucius's works to shed light on Europe's engagement with the Middle Kingdom at the end of the seventeenth century. In this examination, two questions are proposed: how was Confucius represented in print between 1675 and 1700 , and to what extent did the involvement of Dutch authors and translators, printers and publishers shape the representation and dissemination of Confucianism as moral teachings that were compatible with, rather than contradictory to, the Christian beliefs?

To answer these questions, the Dutch encounter with Confucius will be explored to demonstrate that the Jesuit 'invention' of Confucius was a varied and global project. When addressing the European public, Jesuit missionaries required the support of Dutch intermediaries in presenting their accommodation of Confucianism in a favourable light. In turn, the Dutch Republic's prominent role suggests that the manner in which the Jesuits aimed to bridge the gap between China and Europe fitted the cultural and economic needs of Dutch book producers. Publishing strategies focused increasingly on Jesuit sources and representations of China, and publishers effectively functioned as intermediaries between China-based Jesuits and European readers.

This chapter also considers the cultural interactions between the Northern and Southern Netherlands to gain a better understanding of their productive collaboration concerning China. Cooperation between the two Netherlands was extensive both before and after the country split. Numerous Jesuits had originated from the Netherlands; Philippe Couplet was born in Echlin and Nicolas Trigault came from Douai (both in the Southern Netherlands). Godfried Henske and François de Rougemont hailed from Limburg, while François Noël was a Fleming from Hestrud in Hainault; meanwhile, Ferdinard Verbiest was born in Pittem in the County of Flanders. These Jesuits served as a metaphorical bridge between North and South, which the commercial-minded entrepreneurs of the Dutch Republic were more than willing to cross. ${ }^{6}$ Of course, Northern entrepreneurs themselves often had extensive ties with their colleagues in the south and vice versa. Daniel Horthemels, publisher of Confucius Sinarum philosophus, kept in contact with family and colleagues in Zeeland when he departed for Paris, while the Blaeu firm in Amsterdam maintained a large network of business associates in the Southern Netherlands. Furthermore, the VOC and its international membership gave an additional impulse; when Jesuits travelled from Europe to Asia and back, they often did so on voc ships. ${ }^{7}$ Both language and a shared cultural heritage contributed

6 Weststeijn, 'The Middle Kingdom in the Low Countries', pp. 209-242.

7 Hertroijs, 'Hoe kennis van China naar Europa kwam', pp. 65-70. 
to this fruitful exchange of information. Interactions between missionaries, printers and publishers, and merchants transcended religious differences, and numerous individuals benefitted from their mediating position between north and south.

An examination of Kircher's China illustrata of 1667 sheds light on his assertion that Confucianism was a historical continuation of the ancient Egyptian religion. According to Kircher, Egyptian hieroglyphs and Chinese script expressed a Hermetic philosophy of Neoplatonic prisca theologia of pre-Mosaic origins, in which 'ancient gentilism [was] buried under a perverse system of idolatry'. ${ }^{8}$ The spread of idolatry throughout the world was related to the division of tongues, whereby ancient Egypt became the centre of religious diffusionism through the influence of Noah's son, Ham, and his descendants. As such, proto-Christian elements reached all the way to China. However, in the process of transmission, Christianity was corrupted into idolatry, and it was the missionaries' task to re-discover the Christian core of Chinese beliefs. Unfortunately, by declaring Confucianism to be almost identical to the religious system of ancient Egypt, Kircher had undermined the Jesuit strategy of accommodation by presenting Confucius as a nearly god-like figure, comparable to Hermes Trismegistus and Thoth, even though he was careful to note that Confucius was considered a philosopher and not a god.

Kircher's text is further examined to explore how the strategies conceived by his Amsterdam publisher Johannes Janssonius van Waesberge influenced form and content for the purpose of arguing that the monotheistic Confucian literati corresponded to the priestly sages of Egypt, who opposed the cult of idols. However, as we shall learn, subsequent translators and publishers (ab) used text and paratext to argue contradictory points; the French translation of China illustrata by François-Savinien d'Alquié (Amsterdam, 1670) deliberately transformed Kircher's careful description of Confucius as a philosopher into a description of the sage as a God: 'Ce Dieu Confutius'.

To address the questions posed of how Confucius was represented in print, the first Latin manuscript translations of Confucius (ca. 1593-1673) are discussed, and how these came into being through Dutch mediation. The Four Books of Confucius were first translated by Jesuit missionaries in China for the practical purpose of teaching the Chinese language to priests newly arrived in the country. As the education of the Chinese elite began with the

8 Joan-Pau Rubiés, 'Comparing cultures in the early modern world. Hierarchies, genealogies and the idea of European modernity', in Renaud Gagné, Simon Goldhill, and Geoffrey E.R. Lloyd, Frameworks of comparison in history, religion and anthropology (Leiden and Boston: Brill, 2019), pp. 116-176. 
Confucian canon, without mastery of (at least) some of these texts, the Jesuits would certainly fail in their conversion of the Chinese literati. Subsequently, when a publication of this Jesuit translation of Confucius was envisaged, it became impossible to avoid Europe's main centre of book production: the Dutch Republic.

The analysis then moves from the Latin texts to the first printed vernacular translation of Confucius, written by Pieter van Hoorn and published by Johannes van den Eede in Batavia [Jakarta] in 1675. Van Hoorn turned to Confucius for instructions on how to live a virtuous life, even going so far as to argue that 'the Chinese Confucius has expressed and depicted better in words than any European author I know of.' ${ }^{9}$ While his small booklet may have had little clout beyond Batavia, it nevertheless provides valuable first impressions on how Dutch contacts in Asia changed the way in which people like Van Hoorn related to Chinese religion and philosophy.

Furthermore, Confucius Sinarum philosophus will be examined, focusing on how elements of paratext shaped the representation and possible interpretation of the Jesuits' translation of three of the Four Books. Both form and content reveal that the Jesuits' aim was to Christianise Chinese civilisation and Confucius to make it more palatable for a learned European audience. Indeed, Confucius was fitted into 'a scholarly framework that linked the philological principle of the oldest source to the quest for the most ancient wisdom'. ${ }^{10}$ The Jesuits' most original addition to the standard humanistic practices in Europe was thus their emphasis on the Chineseness of their account.

This chapter subsequently discusses two partial French translations of Confucius Sinarum philosophus, published in Amsterdam and Paris in 1688. Sectional translations of Confucius's Great Learning had been made before, most notably by Nathanael Vincent in England and Antonio Possevino in Rome, yet their influence did not extend beyond a small circle of intellectuals. ${ }^{11}$ Through their publisher's networks of distribution and through multiple editions, the French translations facilitated a more general dissemination of

$9 \quad$ 'Nochtans schynt my toe dat den Chineschen Confucius de selve meerder, en klaerder met woorden heeft uyt-gedruckt en afgemaelt als my van eenige Europische Scribenten is te voor gekomen', in Pieter van Hoorn, Eenige Voorname eygenschappen Van de ware DEUGDT, Voorsichtighedt, Wyshydt en Volmaecktheydt (Batavia: Johannes van den Eede, 1675), p. 1.

10 Weststeijn, 'The Middle Kingdom in the Low Countries', pp. 22-222.

11 M. Jenkinson, 'Nathanael Vincent and Confucius's "Great learning" in Restoration England', Notes and records of the Royal Society of London, 6o.1 (2006), pp. 35-47; Knud Lundbaek, 'The first translation from a Confucian classic in Europe', China Mission Studies (1550-1800), 1 (1979), pp. 2-11. 
Confucius's teachings. At the same time, they show how transtextual processes of translation may shape the meaning of a text, especially when the quoted text is not well-known in the target culture, as was the case with Confucius in seventeenth-century Europe. ${ }^{12}$

Combined, the texts analysed in the following pages will reveal that the French translations of Confucius Sinarum philosophus demonstrate how Confucius became a subject to be used and misused by publishers, printers, and editors in furthering their own cultural and economic causes. By looking at how Confucius was represented and to what extent he was manipulated, we will learn how involvement of Dutch authors and translators, printers and published shaped representations and disseminations of Confucianism.

Athanasius Kircher

Called 'the last man who knew everything', 'master of a hundred arts', and 'the last Renaissance man', the German Jesuit, Athanasius Kircher (1602-168o), may very well have been the final 'uomo universale. ${ }^{13}$ His many interests, ranging from geography, astronomy, and mathematics to language, medicine, and music, led to the publication of some 33 books. One of them was an extensive Latin description of China: China monumentis, qua sacris qua profanis, nec non variis Naturae et artis spectaculis aliarumque rerum memorabilium argumentis illustrata (hereafter China illustrata). ${ }^{14}$ The work was published in Amsterdam by Johannes Janssonius van Waesberge in 1667. Kircher had never travelled to China; he based his descriptions on earlier European sources and personal correspondence with an extensive network of Jesuit missionaries in Asia.

While it relied upon accommodative Jesuit sources, Kircher's work was dominated by the hermetic doctrine of prisca theologia (the existence of a single, proto-Christian doctrine, which threads through all religions). He argued that the Chinese were the 'true followers of the Egyptians and the faithful

12 Genevive Roux-Fauchard, 'Intertextualité et traduction', Meta. Journal des Traducteurs, $5^{1}$ (2006), pp. 98-118.

13 Edward W. Schmidt, 'The last Renaissance man. Athanasius Kircher, S.J., Company Magazine (2001-2002); P. Conor Reilly, Athanasius Kircher S.J. Master of a hundred arts, 1602-168o (Wiesbaden: Edizioni del Mondo, 1974); Paula Findlen, Athanasius Kircher. The last man who knew everything (New York: Routledge, 2004).

14 Athanasius Kircher, China monumentis, qua sacris qua profanis, nec non variis Naturae et artis spectaculis (Amsterdam: Johannes Janssonius van Waesberge, 1667). For an overview of Kircher's works, see the bibliography in John Fletcher, A study of the life and works of Athanasius Kircher, 'Germanus incredibilis' (Leiden: Brill, 2011), pp. 565-567. 


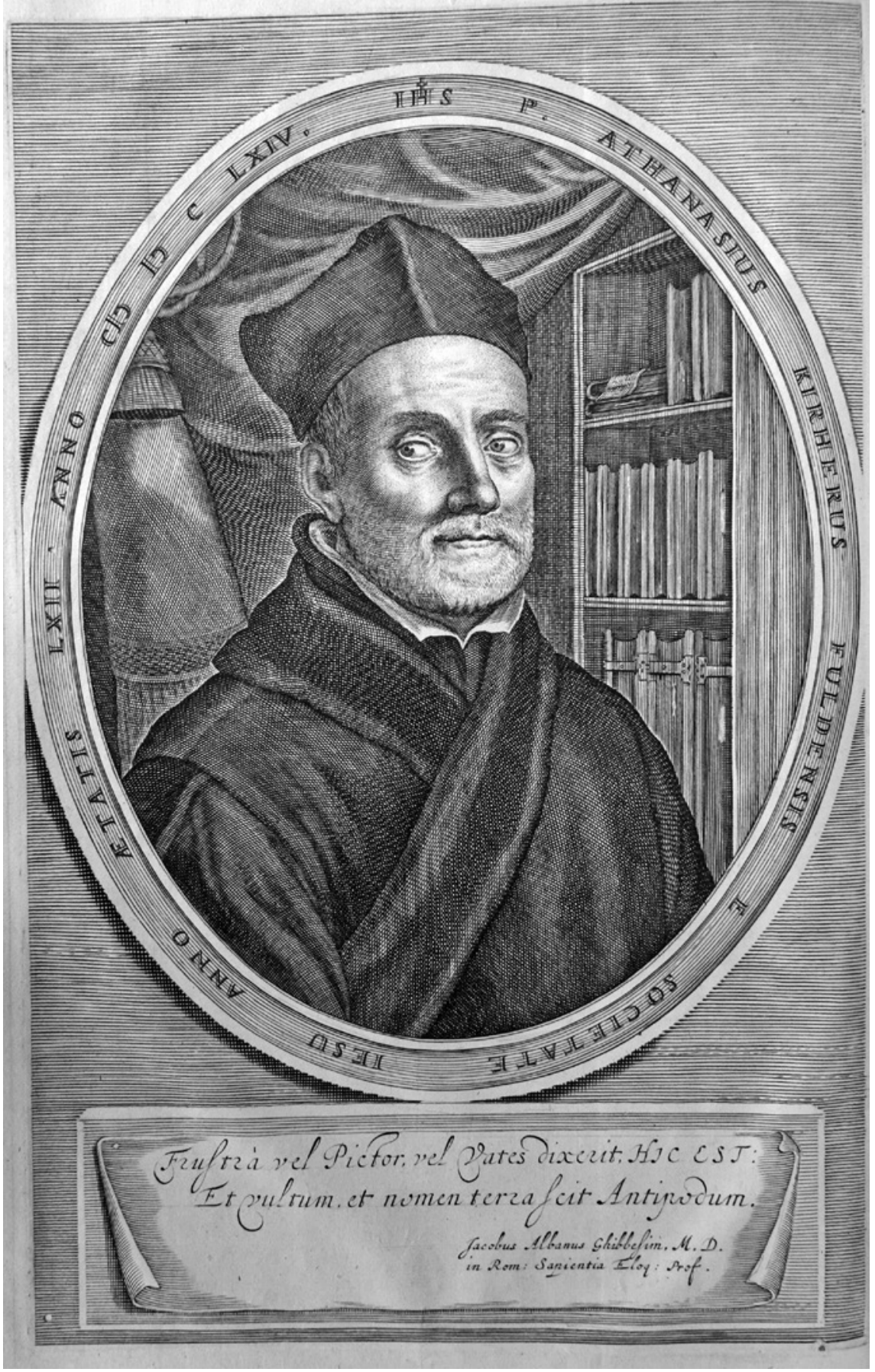

FIGURE 23 Portrait of Athanasius Kircher in Athanasius Kircher, China illustrata (Amsterdam: Johannes Janssonius van Waesberge, 1667) Allard Pierson Amsterdam (Band 4 B 5) 
imitators of their superstitions'. According to him, the religion and philosophy of China resembled that of Egypt to such an extent that the first must be rooted in the second. ${ }^{15}$ The wide range of subjects and the many illustrations in China illustrata made it an important source on Asia in the late 166os and 167os, and many subsequent Dutch publications demonstrated a partial intertextual or paratextual relation with Kircher's description of the Middle Kingdom. This transtextual reach was facilitated by publishing strategies conceived by Kircher and his Amsterdam publisher.

Born in Fulda in Hessen, Kircher entered the Jesuit Order in 1618. He resided in Rome for most of his life, where he functioned as 'a kind of one-man intellectual clearinghouse' of humanistic and scientific knowledge. ${ }^{16}$ At the Collegium Romanum, he curated the 'Museum Kircherianum', a cabinet of curiosities containing various objects from China. ${ }^{17}$ In Rome, Kircher met many missionaries departing for or returning from China. These personal contacts and access to the Jesuit archives and libraries made it easy for Kircher to gather vast amounts of knowledge about the Middle Kingdom. His study of Asia and the Middle East first found expression in works on Egyptian hieroglyphs and missionary discoveries in the Far East. From there followed a work solely devoted to China. ${ }^{18}$

Johannes Janssonius van Waesberge of Amsterdam published China Illustrata in Latin in 1667 , which was printed by the widow Elizaeus Weyerstraten. ${ }^{19}$

15 Kircher, China monumentis, p. 133.

16 'Athanasius Kircher', Encyclopcedia Britannica, 2017 https://www.britannica.com/biography/Athanasius-Kircher, last accessed 22 August 2021; Daniel Stolzenberg, The great art of knowing. The Baroque encyclopedia of Athanasius Kircher (Stanford: Stanford University Libraries, 2001).

17 A catalogue was issued in 1709: Filippo Buonanni, Musaeum Kircherianum sive musaeum ap. Athanasio Kichero in Collegio Romano Societatis Jesu jam pridem incoeptum nuper restitutum, auctum, descriptum, \& iconibus illustratum (Rome: George Plancius, 1709). The museum held (among others things) a rubbing of the Nestorian Stele, made by a Chinese companion of Michael Boym.

18 Jocelyn Godwin, Athanasius Kircher. A Renaissance man and the quest for lost knowledge (New York: Thames \& Hudson, 1979), pp. 50-52.

19 A curious story concerning the printing of China illustrata is related by Isabella van Eeghen. In 1667, Jacob van Meurs brought out a reprint of Kircher's book on China. However, the privilege from the States of Holland of that book lay with Van Waesberge and the widow Weyerstraten, who were Kircher's regular publishers. Of course, Van Waesberge objected to the reprint, and the case was brought before a notary and, by meditation by another bookseller, a settlement was reached on 27 June. Van Meurs handed over everything related to the publication, printed copies, copperplates, woodblocks, for which he would be compensated by Van Waesberge to the sum of fl. 345o, to be paid in instalments of fl. 5 oo. The total sum would (more or less) cover the costs Van Meurs had incurred. Both the amicability of the settlements and the close resemblance of the 
A Dutch edition, translated by Jan Hendrik Glazemaker, was issued in 1668, and partial translations in English and French appeared in 1669 and 1670. ${ }^{20}$ Van Waesberge had obtained the publishing rights to Kircher's works in the Holy Roman Empire, England, and the Low Countries for 2,200 scudi 'for a contract for all his books. ${ }^{21}$ This was a generous amount, and it confirms the commercial viability of Kircher's writings. Before this contract, Kircher's works were primarily printed in Rome, often by Vitalis Mascardi. ${ }^{22}$ Mascardi and Kircher maintained a personal relationship and, after Mascardi's death in April 1666, Kircher may have been looking for another regular publisher. He probably chose Van Waesberge for the quality of his printed works and large distribution

engravings may indicate that Van Meurs had not so much produced a pirated edition, but that his rivals had borrowed some of his 1665 plates for their own work of 1667 . Van Eeghen, 'Arnoldus Montanus's book on Japan', pp. 150-272; Fletcher, 'Athanasius Kircher and the distribution of his books', pp. 108-117; Pettegree and Der Weduwen, The bookshop of the world, pp. 115-120.

20 Athanasius Kircher, Tooneel van China: door veel, zo geestelijke als werreltijke, geheugteekenen, verscheide vertoningen van de natuur en kunst, en blijken van veel andere gedenckwaerdige dingen, geopent en verheerlykt, trans. Jan Hendrik Glazemaker (Amsterdam: Johannes Janssonius van Waesberge, 1668); Athanasius Kircher, La Chine d'Athanase Kirchere De la Compagnie de Jesus, illustrée de plusieurs monuments tant sacrés que profanes, et de quantité de recherchés de la nature \& de l'art, trans. François Savinien d'Alquié (Amsterdam: Johannes Janssonius van Waesberge, 1670); Johan Nieuhof, An embassy from the East-India Company of the United Provinces, to the Grand Tartar Cham, emperor of China: delivered by their excellencies Peter de Goyer and Jacob de Keyzer, at his imperial city of Peking wherein the cities, towns, villages, ports, rivers, \&c. in their passages from Canton to Peking are ingeniously described by John Nieuhoff; also an epistle of Father John Adams, their antagonist, concerning the whole negotiation; with an appendix of several remarks taken out of Father Athanasius Kircher; Englished and set forth with their several sculptures by John Ogilby, trans. John Ogilby (London: for the author, 1673); Paul Begheyn, 'Athanasius Kircher sj (1602-1680) en zijn contacten in Nederland', in J. van Gennip and M.A. Antoinette Th. Willemsen, Het geloof dat inzicht zoekt. Religieuzen en de wetenschap (Hilversum: Uitgeverij Verloren, 2010), pp. 84-93.

21 'In vigore del nostro contratto per tutti i suoi libri', in Archive Pontifica Università Gregoriana, Rome, Misc. Epist. Kircher, 56o, fol. 79r; see: Noël Golvers, 'The development of the Confucius Sinarum philosophus reconsidered in the light of new material' in Roman Malek, Western learning and Christianity in China. The contribution and impact of Johann Adam Schall von Bell, S.J. (1592-1666) (Nettetal: Steyler Verlag, 1999), pp. 1141-1164, p. 1149. On the publishing rights, see: Stolzenberg, The great art of knowing, p. 10. 
network. ${ }^{23}$ According to historian Martha Baldwin, by accepting a lump sum, Kircher freed himself from worries over publication expenses by entering into this unusual business arrangement with Van Waesberge. Such long-term publishing arrangements were, indeed, still a rarity in the seventeenth century. From 1665 onwards, almost all of Kircher's new books were published by Van Waesberge. He also reissued several of Kircher's earlier works, and published a number of vernacular translations. In the words of historian Daniel Stolzenberg: 'The team of Jesuit author and Protestant printer symbolized the cosmopolitan appeal of Kircher's books.'. ${ }^{4}$

When China illustrata was published 1667, Dutch book production had reached an exceptional level of quality. As we have seen in the previous chapter, Jacob van Meurs had initiated a publishing strategy in which travelogues and descriptions of foreign countries were published in folia, lavishly illustrated with dozens of engravings. Van Waesberge decided on the same strategy for his edition of Kircher's China illustrata. The book appeared in large folio, illustrated by 56 engravings, a portrait of Kircher, a map of China, and a transcription of the text on the Nestorian Stele. Thanks to the combined international networks of Van Waesberge in Amsterdam and Kircher in Rome, the work was distributed throughout Europe. Even today, the number of copies held by libraries, from Scandinavia to Spain and beyond, is striking and attest to the efforts of both author and publisher. One of the copies held by the Allard Pierson Amsterdam was even intended for the papacy. It is bound (perhaps at the request of Kircher or Van Waesberge) in red Moroccan leather by Amsterdam master binder, Albert Magnus. ${ }^{25}$ This binding bears the coat of arms of the Rospigliosi family of Pope Clement IX (1667-1669). This crest was made out of a separate piece of leather and pasted over the coat of arms of

23 A.M. Ledeboer, Het geslacht Van Waesberge. Eene bijdrage tot de geschiedenis der boekdrukkunst en van den boekhandel in Nederland (Rotterdam: Widow P. van Waesberge en zoon, 1859).

24 Stolzenberg, The great art of knowing, p. 9.

25 Held at the University of Amsterdam: отм: Band 4 B 5. Mirjam Foot argues that many of the bindings attributed to Magnus were not made by the master himself. An additional four luxury bindings of Kircher's works are held at the Royal Library in The Hague as part of the collection of Sir Herbert Thomas. These also must have been presentation copies; their copy of China illustrata also bears the coat of arms of Pope Clemens XI. Furthermore, a beautifully bound copy in the Röhsska Konstslöjd Museet in Götenborg was also seemingly intended for the Pope. It was not unusual for several copies of the same book in luxury bindings to be presented simultaneously, Mirjam M. Foot, Studies in the history of bookbinding (London: Scolar Press, 1979), p. 246; Herman de la Fontaine Verwey, 'The binder Albert Magnus and the collectors of his age', Quaerendo, 1 (1971), pp. $15^{8-178 .}$ 


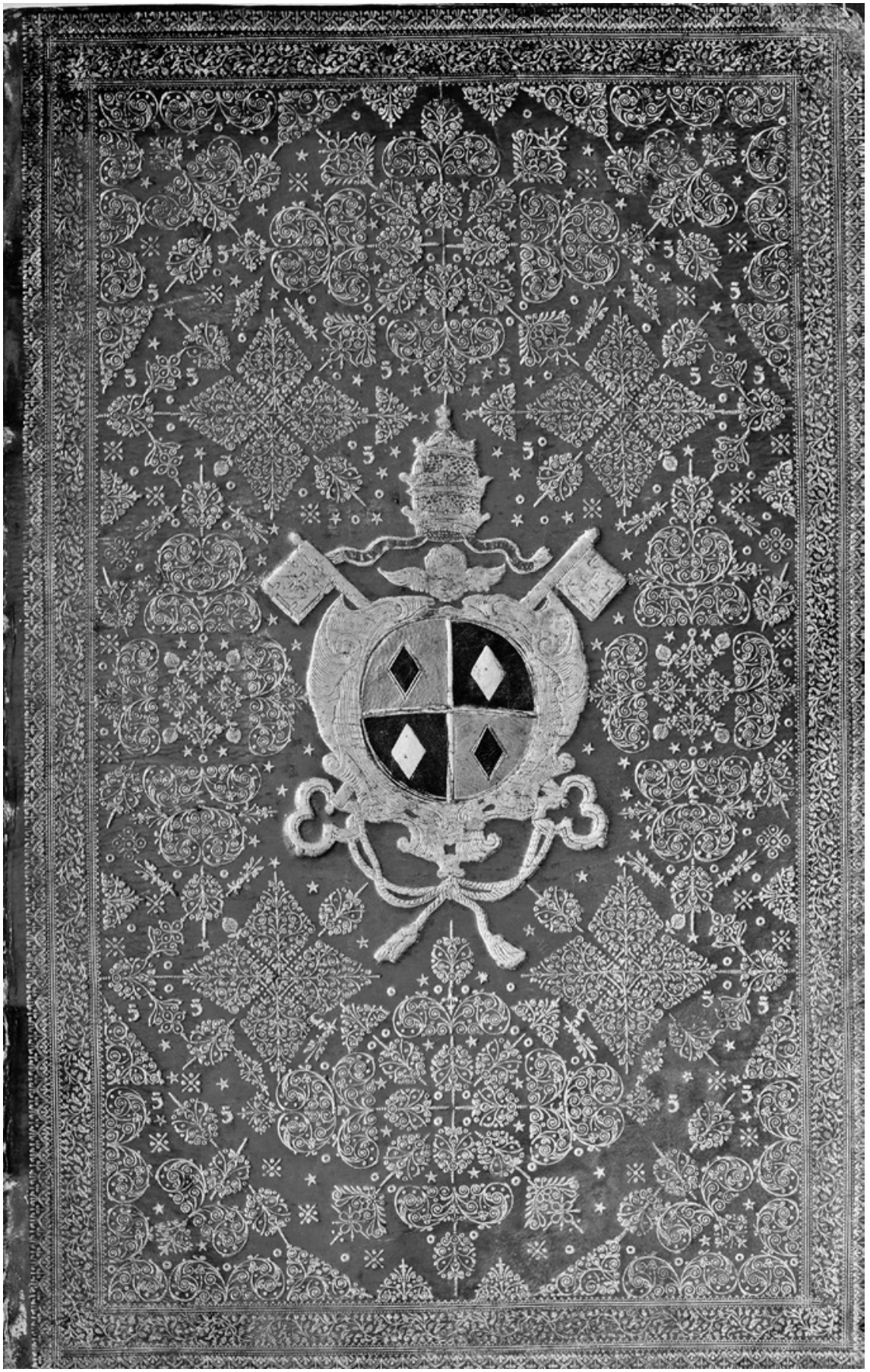

FIGURE 24 Red moroccan binding made by Albertus Magnus for Pope Clement IX. Allard Pierson Amsterdam (Band 4 B 5) 
the Chigi family of Pope Alexander VII $\left(1655^{-1667)}\right.$, who died in 1667 and was succeeded by Clement.

Kircher's China illustrata is not only a compilation of knowledge gathered by European merchants and missionaries, it also includes a collection of previously unpublished materials on geography, botany, zoology, languages, religion, and antiquities. ${ }^{26}$ As such, it is considered one of the earliest examples of European Sinology. ${ }^{27}$ The first part of the book is intended to demonstrate the authenticity of the Nestorian Stele, or Jingjiao bei 景教碑, that was unearthed beside the Chongren Temple 崇仁寺 at Xi'An, Shaanxi Province in 1625. This limestone monument was erected in 781 , and its inscriptions in Chinese and Syriac relates the early presence of Christians in Northern China. ${ }^{28}$ China illustrata is the first book in Europe to include a transcription of the original Sino-Syriac on the Stele, together with an engraved reproduction of its original Chinese characters, a Romanisation of the text, and a Latin translation. ${ }^{29}$

Kircher's chapter on religion and philosophy is provocatively entitled 'On the idolatry of the Chinese. ${ }^{30}$ His contention that China was idolatrous stood in service of the hermetic notion of prisca theologia, which holds that there exists a single theology, given by God to man, that spreads through all religions. According to Kircher, Christianity was rooted in ancient Egypt. Idolatry arose when this Egyptian proto-Christianity spread, but was misinterpreted outside of Egypt. ${ }^{31}$ Persia, India, Tartary, Japan, and China were influenced by this distorted form of Christianity coming from Egypt.

Kircher stated that there were three sects in China: that of the 'scholars' (Confucius), the sect of 'Sciequia' (Sakyamuni) Buddha, and the sect of 'Lancu' (老子 Laozi), the Taoists. He might have derived this division from Nicolas

26 Charles D. Van Tuyl, China illustrata by Athanasius Kircher, S.J. (Muskogee: Indian University Press, 1987).

27 Mungello, Curious land, pp. 134-173.

28 Keevak, The story of a stele, pp. 61-89; Wang Ding, 'Remnants of Christianity from Chinese central Asia in Medieval ages', in Roman Malek, Jingjiao. The Church of the East in China and central Asia (Sankt Augustin: Insitut Monumenta Serica, 2006), pp. 149-162.

29 Mungello, Curious land, pp. 164-173; Kircher, China illustrata, pp. 13-28. This translation was made by Michael Boym and two Chinese converts - Andreas Zheng 郑安德勒 and the anonymous 'Matthaeus Sina', who visited Rome in the middle of the century. Monika Miazek-Meczynska, 'The Roman troubles of Michael Boym S.J. Described by Szpot Dunin in Historiae Sinarum Imperii and Collectanea Historiae Sinensis', in Barbara Hoster, Dirk Kuhlmann and Zbigniew. Wesolowski, Rooted in hope. Festschrift in honor of Roman Malek S.V.D. (Sankt Augustin: Monumenta Serica Institute, 2017), pp. 173-185.

$30 \quad$ 'Van d'Afgodendienst', in Kircher, Tooneel van China, p. 158.

31 Daniel Stolzenberg, Egyptian Oedipus. Athanasius Kircher and the secrets of Antiquity (Chicago: University of Chicago Press, 2015), pp. 151-180; Weststeijn, 'The Chinese Isis', pp. 301-313. 
Trigault and Matteo Ricci's De Christiane expeditione apud Sinas, discussed in a previous chapter. This categorisation was widely agreed upon and not necessarily inaccurate. However, in contrast to Trigault and Ricci, Kircher argued that these three sects were directly related to ancient Egyptian society and its division into priests, scribes, and common people. The followers of Confucius thus correlated to the priests, and common people followed Laozi. The equation of Buddhism with the scribe class of Egypt is not explicitly made. ${ }^{32}$

Kircher noted how the sect of the geleerden ('scholars'), those following the teachings of Confucius, had the greatest esteem in China. ${ }^{33}$ However, while he echoed Trigault and Ricci in his description of the Chinese literati and their veneration of Confucius, he ignored those Chinese rites that the Jesuits defended as permissible. Instead, Kircher selected only those examples that supported his own claims of the Egyptian origins of Chinese idolatry. ${ }^{34}$ Kircher provided an excerpt from Trigault to argue that there were similarities between Chinese animal sacrifices to the 'Lord of Heaven' and those made by the ancient Egyptians to the god Osiris. He also used Trigault to claim similarities between the rites carried out in Confucian temples and the rituals celebrated in Egypt to Thoth (known to the Greek as Hermes Trismegistus):

They sacrifice a great number of oxen and sheep to the Heaven and Earth (no different than the Egyptians to Osiris and Isis) and dedicate many other ceremonies to them. Furthermore, there is a certain temple of the literati, dedicated to Confucius himself, the prince of Chinese philosophy: these are built, according to law, in every city, in a place that protrudes above the school. ${ }^{35}$

While Kircher's idiosyncratic interpretation of the Chinese rites does not fully follow that of the Jesuits, he is careful to note that Confucius is considered a

$32 \quad$ Mungello, Curious land, p. 135.

33 Kircher, Toonneel van China, p. 16o.

34 Florence Hsia, 'Athanasius Kircher's China illustrata (1667)', in Findlen, The last man who knew everything, pp. 383-404, p. 388; Mungello, Curious land, pp. 159-160; Rubiés, 'Ethnography, commensurability and the use of comparison', pp. 138-141.

'Zy offeren ossen en schapen in groot getal aan de Hemel en Aarde (niet anders dan d'Egiptenaars aan Osiris en Isis) en bewijzen veel andere plechtelijkheden aan hen. Wijders, daar is een eige tempel der Geleerde, aan Konfucius zelf, de vorst der Sinesche Wijsbegerigen, gewijd: deze word, volgens de Wetten, in yder stat voor hem gebout, namelijk in een plaats, die boven het School uitsteekt.' in Kircher, Toonneel van China, p. 161; Kircher, China illustrata, p. 132. Notably, the reference to Isis is only found in the Latin (1667) and Dutch (1668) edition by Van Waesberge, but is omitted from the Latin edition (1667) of Van Meurs and the French edition (1670) of Van Waesberge. 
'philosopher' and not a god. Notably, the French translation of China illustrata by François-Savinien d'Alquié (Amsterdam, 1670) departs from this wording. Although he quotes the same passage from Trigault, he alters it substantially (and probably not innocently), making Confucius into a god: compare 'Confutii philosophorum Sinensium' to 'ce Dieu Confutius.' ${ }^{36}$

Kircher's account of Chinese religion and philosophy continues with a condemnation of both Buddhism and Taoism, focusing on their worship of idols: 'As the almost impossible to believe number of idols sufficiently demonstrates, which number in the thousands and which are not only shown in temples to be worshipped, but also in almost every house or place that may be suitable' ${ }^{37}$ Kircher ends the chapter by recapitulating his claim that the Chinese are the 'true followers of the Egyptians and the faithful imitators of their superstitions. ${ }^{38}$ Not only did the Chinese worship the same gods as the ancient Egyptians with the same customs and ceremonies, but Chinese characters and script also resembled the hieroglyphs of the Egyptians. Thus, according to Kircher, the Egyptian hieroglyphs were symbolic references to Christian truths, which were retained in Chinese characters. As such, the missionaries only needed to explain this to the Chinese, who (they believed) had forgotten the Christian essence of their own civilisation over time. According to Joan-Pau Rubiés, Kircher's attempts to argue for the Hermetic-Egyptian-Chinese narrative may have often run counter to the efforts of his fellow Jesuit missionaries. ${ }^{39}$

By the middle of the seventeenth century, the dispute was well under way concerning the question whether Chinese ritual practices of honouring family ancestors and other formal Confucian and imperial rites qualified as religious and thus incompatible with Christianity. This dispute led to clashes with members of the Dominican and Franciscan orders, who disagreed with the Jesuits and reported the issues to Rome. By presenting Confucianism as a system of religion that was identical to that of ancient Egypt and by comparing Confucius to the seemingly deified figures of Thoth and Hermes Trismegistus, Kircher undermined the Jesuits' delicate strategy of accommodation.

Furthermore, much of the Chinese Rites Controversy centred around the debate whether the Jesuits accurately understood Chinese beliefs and

$36 \quad$ Kircher, China illustrata, p. 132; Kircher, La Chine d'Athanase Kirchere, p. 176.

37 'Gelijk de byna ongelooffelijke menigte der beelden genoech te kennen geeft, dewelken dikwijls tot een getal van enige duizenden niet alleenlijk in de tempelen worden vertoont, om aangebeden te worden, maar ook byna in alle bezondere huizen, ter plaats, die daar toe geschikt is', in Kircher, Toonneel van China, pp. 163-164.

38 'Daar in zy d'Egiptenaars, om de menigvuldige verscheidenheit van hun afgoden bericht, na te volgen', in Kircher, Toonneel van China, p. 164.

Rubiés, 'Ethnography, commensurability and the use of comparison', pp. 141-143. 
practices; according to a contemporary, 'the whole question boils down to a point of fact: to known what the Chinese think about their Confucius and their ancestors, and what they intend by the ceremonies with which they honour them'. ${ }^{40}$ Kircher's reply was that his fellow Jesuits certainly understood Chinese civilisation as they possessed the requisite linguistic facilities. Indeed, he often praised their skills in Chinese, Japanese, Tartar and Indian languages. Over the course of the seventeenth century, the Jesuits had put these skills to good use by translating three of the Four Books of Confucius from Chinese into Latin, ostensibly to justify their missionary policy in China to a European audience. However, as subsequent sections will show, the results of these efforts may have been less successful than they perhaps expected. Eventually, the publication of Confucius Sinarum philosophus only exacerbated the problem by highlighting the most contentious issues.

The texts compiled in Confucius Sinarum philosophus were written over the course of almost a century by at least 17 missionaries from Austria, Italy, the Low Countries, and Portugal, who were assisted by many Chinese interlocutors. ${ }^{41}$ The first attempts at publication involved printers in China and India. Subsequently, when a European audience was envisaged, the importance of the Dutch Republic as a nucleus of printing and publishing made itself felt.

According to Thierry Meynard, 'the Jesuits accumulated one hundred years of expertise in reading the Four Books and their commentaries' that formed the basis of their translation of Confucius Sinarum philosophus. ${ }^{42}$ As the core of the Confucian canon, three volumes of the Four Books (Sishu 四書) were translated into Latin: the Great learning (Daxue 大學), the Doctrine of the mean (Zhongyong 中庸), and the Analects (Lunyu 論語). ${ }^{43}$ The missionaries' involvement with Confucius had initially been a practical one. The Jesuits recognised that the success of converting a nation from the 'top down' depended upon obtaining followers among powerful and influential individuals so that they

40 Préjugez légitimes en faveur du décret de N.S. Père Alexandre VII et de la pratique des Jésuites au sujet des honneurs que les Chinois rendent à Confucius et à leurs ancestres, [s.l.s.n.], 170o, p. 2, as cited in Rule, K'ung-tzu or Confucius?, p. 70.

41 Meynard, Confucius Sinarum philosophus (1687), pp. 12-18.

42 Meynard, The Jesuit reading of Confucius, p. 18.

43 The Jesuits did not include the fourth book, Mencius 孟子, which is a collection of moral and political philosophy by the Confucian thinker and philosopher Mencius, written somewhere around 300 BCE. 
could influence lower-class individuals to follow their example. ${ }^{44}$ In order to do so, the Jesuits had to appeal to the Confucian literati by way of mastery of the Chinese language combined with a knowledge of at least some of the Confucian texts: without these two basic prerequisites, any attempts at conversion would certainly fail. ${ }^{45}$

Owing to such practical purposes as language acquisition, only few of the early Jesuit translations of the Confucian classics have survived. The oldest, held at the Biblioteca Nazionale in Rome, is by Michele Ruggieri, who arrived in China in $1579 .{ }^{46}$ Only a fragment was printed in 1593 in a book on Jesuit education. ${ }^{47}$ A Spanish manuscript entitled Disciplina de los Varones. Libro primero de los que comunemente se dizen en la China los quatro libros of the late 158 os also contained partial translations of Confucius. This translation was sent to Philip II of Spain and was signed by Ruggieri, even though the real author may have been Matteo Ricci. ${ }^{48}$

Between 1659 and 1667, the Portuguese missionary Inácio da Costa and the Italian Prospero Intorcetta translated the Great learning and the first half of the Analects, published in 1662, entitled, Sapientia Sinica, by a Chinese printer in Jianchang in Jianxi province. This book interspersed Chinese characters with Romanised phonetic transcriptions, as well as their Latin equivalents, and Jesuit commentaries. ${ }^{49}$ Intorcetta proceeded to translate the Doctrine of the mean, with an expanded biography of Confucius, which was finished under the title of Sinarum scientia politico-moralis in 1667. The complete book, a bilingual Chinese-Latin edition, was published two years later. The first half was printed in Guangzhou in 1667 and the second half in Goa, India in 1669. Intorcetta was on his way back to Europe then, to prepare a publication of

\footnotetext{
44 Mungello, The great encounter of China and the West, pp. 23-25.

45 Brockey, The journey to the East, pp. 243-286.

46 Meynard, Confucius Sinarum philosophus, p. 8; Michele Ruggiere, 'China, seu humana institutio', Biblioteca Nazionale, Rome, Fondo Gesuitico (FG) 1185 (3314).

47 This was a fragment of The Great Learning, in Antonii Possevino, Bibliotheca selecta quae agitur de Ratione Studiorum t. I, Rome: s.n., 1593, lib. IX, p. 583. See Lundbaek, 'The first Translation from a Confucian Classic in Europe', pp. 2-11.

48 Disciplina de los varones. Libro primero de los que comunemente se dizen en la China los quatro libros, Real Biblioteca del Monasterio di San Lorenzo el Escorial, MS III C 27, 1590; a translation in Italian was published in 2016, Confucio: La morale della Cina. Ovvero il Grande Studio, l'invariabile Mezzo e parte dei Dialoghi tradotti nel 1590 dal gesuita Michele Ruggieri per sua Maetà Filippo II (Rome: De Luca Editori d'Arte, 2016); see also Diego Sola García, Cronista del China. Juan González de Mendoza, entre la misión, el imperio y la historia (Barcelona: Edicions de la Universitat de Barcelona, 2018), pp. 55-56.

49 Inácio da Costa and Prospero Intorcetta, Sapientia Sinica (Kien C'ham in urbe Sinaru Provinciae Kiam Si, 1662).
} 
the Confucius translations for a European readership outside the context of linguistic education.

At this point, it became hard to avoid Europe's main centre of book production: the Dutch Republic. Da Costa's original collaborators in China had included François de Rougemont from Maastricht and Philippe Couplet from Mechelen, who suggested to involve Amsterdam publisher Joan Blaeu. They had become acquainted with Blaeu just before their departure for China from Amsterdam on a voc ship. ${ }^{50}$ In 1663 , having safely arrived in the Middle Kingdom, De Rougemont and Couplet sent Blaeu their greetings via a voc official: 'We wish to send from me and Mr. Franciscus Rougemont greetings ... to Mr. Blauw [sic].'51 Five years later, De Rougemont mentioned the Amsterdam publisher again as his preferred choice for the publication of the Confucian texts. ${ }^{52}$ Even though they were Protestants (probably Mennonites), Joan Blaeu and his father Willem Jansz were an obvious choice: their renowned firm was responsible for many publications by Jesuit authors, including Martino Martini's Atlas Sinensis. ${ }^{53}$ Blaeu had regularly acted as a dependable middleman, enabling the Jesuits to send letters to and from China via de voc. In turn, he counted on the privilege of being the first in Europe to publish important Chinese sources and studies. ${ }^{54}$

Yet, when Intorcetta returned to Europe with the translations of Confucius in 1671 , he came under the protection of Athanasius Kircher, who at the time was already based at the Jesuit college in Rome. Kircher 'did not want Blaeu to withhold' the manuscript and proposed that his Amsterdam publisher, Johannes Janssonius van Waesberge, take on the project. ${ }^{55}$ When Intorcetta

$5^{\circ}$ In Amsterdam, they stayed at the covert, yet condoned Jesuit mission post, innocuously called 'The Sunflower'.

51 'Soo soude van mynent wegen ende van wegen van mynheer Franciscus Rougemont te groeten ..., mynheer Blauw'. AA.v.v., Dagh-register, gehouden in 't kasteel Batavia, 1633 (The Hague: 1904), p. 304; John E. Wills, 'Some Dutch sources on the Jesuit China mission, 1662-1687', Archivum historicum Societatis Iesu, 54 (1985), pp. 267-294, p. 271.

52 Meynard, Confucius Sinarum philosophus, p. 12; Golvers, 'The development of the Confucius Sinarum philosophus', pp. 1141-1164, p. 1144.

53 Paul Begheyn, Jesuit books in the Dutch Republic and its generality lands, 1567-1772. A bibliography (Leiden: Brill, 2014), pp. 44-45.

54 Intorcetta had already wanted to print the Politico-moralis in the Dutch Republic. See Noël Golvers, 'An unobserved letter of Prospero Intorcetta, S.J. to Godefridus Henschens, S.J. and the printing of the Jesuit translations of the Confucian Classics (Rome-Antwerp: 2 June 1672)', in Dirk Sacré and Jan Papy, Syntagmatia. Essays on Neo-Latin literature in honour of Monique Mund-Dopchie and Gilbert Tournoy (Leuven: Leuven University Press, 20o9), pp. 679-698.

55 ' $\mathrm{N}]$ on vorria io che il Blaeu le trattenesse', Archive Pontifica Università Gregoriana, Rome, Misc. Epist. Kircher, 56o, fol. 79r; see Golvers, 'The development of the Confucius Sinarum 
left Rome in 1672, another Jesuit from the Netherlands, Godfried Henske, considered publishing the translations, but Kircher again intervened and had the texts transferred from Amsterdam to Rome. The reasons for this displacement remain unclear. Meynard has speculated that this decision may have been connected with the current Dutch wars with France and Britain, or that Kircher himself wanted to supervise the publication. ${ }^{56}$ The first option seems plausible, were it not for the fact that Kircher continued sending his own manuscripts to Amsterdam during this period. ${ }^{57}$ Regardless, owing to Kircher's old age and eventual death in 1680, the manuscript remained unpublished in Rome for over a decade. ${ }^{58}$

In the meantime, a copy of Intorcetta's translation had fallen into the hands of the Italian philosopher Lorenzo Magalotti, who had passed it on to Melchisédech Thévenot. This eminently connected scholar was working on a substantial book about the non-European world, Relations de divers voyage curieux. Its fourth volume (1672-1673) incorporated Intorcetta's Latin translation of the Doctrine of the mean, printed without the Chinese characters but including the biography of Confucius in both Latin and French. ${ }^{59}$ Relations, counting 1,700 pages in total, also included French translations of Martini's Atlas and other Dutch sources, such as Willem IJsbrantsz Bontekoe's previously discussed popular East India travelogue in Dutch and the Dutch report of the voc embassy by Johan Nieuhof. Apparently, Christiaan Huygens had sent Thévenot clandestine excerpts from Nieuhof's account in 1662, three years before its publication in Dutch. ${ }^{60}$ Thus without explicit consent, the Jesuit translation of Confucius was presented for the first time outside a missionary

philosophus', pp. 1145-1146, p. 1149. On the publishing rights, see Stolzenberg, The great art of knowing, p. 10.

56 Meynard, Confucius Sinarum philosophus, p. 13, which refers to a letter from Kircher to Henskens, 2 July 1675; Golvers, 'An unobserved letter of Prospero Intorcetta'.

57 Van Waesberge published Kircher's Principis christiani archetypon politicum sive sapientia regnatrix (1672), Arca Noë (1675), and Sphinx mystagoga (1676).

58 Meynard, Confucius Sinarum philosophus, p. 15.

59 'La science des Chinois, ou le Livre de Cum-fu-çu, traduit mot pour de la langue chinoise par le R.P. Intorcetta jesuite. Chum yum constanter tenedum', in Melchisedec Thévenot, Relations de divers voyage curieux (4 vols., Paris: Sebastien Mabre-Cramoisy, 1663-1696), IV, pp. 1-24 (only the title is in French, the text itself is in Latin).

6o Huygens to Thévenot, July 1662, appendix 'Ex itinerario Chinensi Hollandorum Anno 1656.57', in Christiaan Huygens, Oeuvres completes (The Hague: 1894), vol. 4, nos. 10381039. Huygens wrote to his brother Lodewijk on 13 July 1662 (vol. 4, p. 169): 'Je veux aussi luy envoier un Extrait du Voiage en la Chine, que jén ay tirè lors que je léus entre mes mains, je dit cette Relations quíl si fort desirè d'avoir.' 
context to a much broader European readership in Thévenot's large and multifaceted publication.

It took the Jesuits nearly a century to translate Confucius, helped by at least 17 missionaries and various interlocutors in both Europe and Asia. What had started as an exercise in Chinese language acquisition at the end of the sixteenth century, soon turned into the foundation of the Jesuit missionary policy in the Middle Kingdom. When the Jesuits turned their attention towards a more general readership in Europe, in part to justify their accommodation of various Chinese rites, Protestant Dutch intermediaries often facilitated this early dissemination of the translations of Confucius.

\section{The 1675 Dutch Edition of Confucius}

The first printed vernacular translation of Confucius was made by Pieter van Hoorn in Batavia in 1675. Van Hoorn, a gunpowder manufacturer, had been appointed member of the voc Council of the Indies and left Amsterdam for Batavia in 1662. In 1666, he led an embassy to the imperial court in Beijing to gain right of trade. While the journey proved a political and economic bust, Van Hoorn's reports did reap some reward as the basis of the aforementioned book by Olfert Dapper, Gedenkwaerdig bedryf der Nederlandsche Oost-Indische maetschappye, op de kuste en in het keizerrijk van Taising of Sina.

After his return to Batavia, Van Hoorn composed a verse translation of parts of Confucius's Analects entitled, Eenige voorname eygenschapen van de ware deugdt, voorsichtigheydt, wysheydt en volmaecktheydt ('Some principle characteristics of true virtue, prudence, wisdom, and perfection'). ${ }^{61}$ He probably used a (manuscript) translation made by the Jesuits as his source-text, yet this Dutch version may also have dealt with original Chinese sources as Van Hoorn lived alongside a sizeable community of Chinese people in Batavia. The small booklet in quarto contains only three quires on inexpensive paper without illustrations, which is probably why historians have all but ignored it; in the words of Wilt Idema: 'It is highly questionable whether Van Hoorn's faint echo of the nation's enthusiasm for China was ever heard in patria.' ${ }^{62}$

61 Pieter van Hoorn, Eenige voorname eygenschappen van de ware deugdt, voorsichtigheydt, wysheydt en volmaecktheydt. Getrocken uyt den Chineschen Confucius (Batavia [Jakarta]: Johannes van den Eede, 1675).

62 Wilt Idema, 'Confucius Batavus. Het eerste Nederlandse dichtstuk naar het Chinees', Literatuur, 16 (1999), pp. 85-89, p. 86. 
Nevertheless, this forgotten booklet raises many questions. Notably, Van Hoorn's translation was printed in Batavia, not necessarily a centre of book production, although the Dutch had operated a small printing press there for some time. ${ }^{63}$ Supplies of printer's ink, the lye bath, plates, and paper all had to be ordered from Europe. The output of the Batavian press consisted mainly of treaties, regulations, and notices as well as some dictionaries, wedding poems, and catechisms. ${ }^{64}$ In 1674-1675 Johannes van den Eede, formerly of Middelburg, was printing and publishing for the voc in the Prinsentraat under the imprint 'De Batavische mercurius'. ${ }^{65}$ He printed only two other works besides the Confucius translation during that time, which is in line with the general output of the Batavian press in this period. ${ }^{66}$ Because the publication of Confucius does not fit within the usual Batavian corpus of publications, it is possible that Van Hoorn paid for it out of his own pocket. This would also explain why he dedicated the work to his family instead of, as was the usual practice, the voc and its board of directors.

Van Hoorn believed that Confucius's instructions on how to lead a virtuous life were more adequate than any Western work could provide: 'Much has been written about virtue.... But it seems to me that the Chinese Confucius has expressed and depicted it with words better and clearer than any European author. ${ }^{\prime} 7$ According to Peter Rietbergen, his open-mindedness towards Confucius was an attempt 'to bridge the gap between ethical, social and societal principles propounded by the Chinese thinker and his own Christian culture'.68 What is more, Van Hoorn's engagement with Chinese thought was markedly different from that of his contemporaries. Nowhere does he make

63 Landwehr, A bibliography of publications relating to the Dutch East India Company; Katharine Smith Diehl, Printers and printing in the East Indies to 1850, vol. I, Batavia 160o1850 (New Rochelle: Aristide D. Caratzas, 199o).

64 Short Title Catalogue Netherlands; place of publication = Batavia.

65 J. Landwehr, 'De VOC in de wereld van het boek. Sponsor en uitgever', De Boekenwereld, 6 (1989-1990), pp. 134-135.

66 Between 1668 and 1708, 40 books were printed and published in Batavia according to the Short Title Catalogue Netherlands. This number should be taken with some caution. Much of the printed works never reached the Netherlands, and the climate in the Indies did not contribute to the durability of paper. Also, much of the Batavian print was meant for heavy duty usage: as a rule of thumb, such things are seldom preserved in large quantities.

67 'Over de deugdt is veel geschreven ... nochtans schynt my toe dat den Chineschen Confucius de selve meerder, en klaerder met woorden heeft uyt-gedruckt en afgemaelt als my van eenige Europische Scribenten is te voor gekomen.' in Van Hoorn, Eenige voorname eygenschappen, p. 1 .

68 Peter Rietbergen, 'Before the Bible, beyond the Bible ...? VOC travelogues, world views and the paradigms of Christian Europe', in Susanne Friedrich, Transformation of knowledge in Dutch expansion (Berlin: De Gruyter, 2015), pp. 231-249, p. 237. 
the explicit comparison between Confucius and Christ or the biblical prophets, a rhetoric often employed by the Jesuits. In fact, even Europeans who were sceptical of the Society of Jesus did not hesitate to portray the Chinese philosopher as a kind of Christian saint. ${ }^{69}$ By contrast, Van Hoorn only indicated that the original author lived before Christ, thereby allowing readers to draw their own conclusions.

Earlier historians have suggested that Van Hoorn used a translation made by the Jesuits as his source-text. This cannot have been the printed Sapientia Sinica, which provides only the first half of the Analects; Van Hoorn included passages from the whole text in his work. ${ }^{70} \mathrm{He}$ may, however, have had access to a manuscript version of Couplet's complete translation. ${ }^{71}$ Relations between voc officials and Jesuits have been amply documented: missionaries often travelled on Dutch ships, which also carried their mail. Martino Martini for instance, stayed for six months in Batavia in 1653 and so did Couplet for 13 months in 1682-1683. Governor-General Johannes Maetsuyker (a Catholic) was even suspected of actively supporting the Jesuits. ${ }^{72}$ Van Hoorn likewise befriended Philippe Couplet, even though he nurtured no evident sympathies towards Catholicism. ${ }^{73} \mathrm{He}$ may therefore have been interested in Confucius for different reasons.

What indications do the different texts provide? A complicating factor is that, in the seventeenth century, Confucius's statements were available in several editions with elaborate commentaries. ${ }^{74}$ Perhaps Van Hoorn and the Jesuits used different editions? In James Legge's modern translation, the opening lines of the Analects read:

69 In his Vertu des païens (1641), the libertine philosopher François La Mothe le Vayer exclaimed (echoing Erasmus's statement on Socrates): 'Sancte Confucius, ora pro nobis.' Pierre Hazard, La crise de la conscience européenne, 1680-1715 (Paris: Librairie générale Française, 1961), p. 21.

70 Sapientia Sinica also includes the complete Great learning, but Van Hoorn did not refer to it.

71 Idema, 'Confucius Batavus', p. 86.

72 Marion Peters, De wijze koopman. Het wereldwijde onderzoek van Nicolaes Witsen (16411717), burgemeester en VOC-bewindhebber van Amsterdam (Amsterdam: Bert Bakker, 2010), pp. 226-227. Hertroijs, 'Hoe kennis van China naar Europa kwam', p. 17.

73 Van Hoorn met with Couplet and De Rougemont during his sojourn at Fuzhou, according to Leonard Blussé, 'Doctor at sea. Chou Mei-Yeh's voyage to the West (1710-1711)', in Erika de Poorter (ed.), As the twig is bent ... Essays in honour of Frits Vos (Amsterdam:J.C. Gieben, 1990), pp. 7-30, p. 14.

74 When the Jesuits translated the Four Books, it is very likely that they used an edition comprising both the Sishu jizhu [by Zhu Xi] and the Sishu zhijie [by Zhang Juzheng], see Meynard, The Jesuit reading of Confucius, p. 40. 
The Master said, 'Is it not pleasant to learn with a constant perseverance and application? Is it not delightful to have friends coming from distant quarters?' ... Tsze-hsia said, 'If a man withdraws his mind from the love of beauty, and applies it as sincerely to the love of the virtuous; if, in serving his parents, he can exert his utmost strength; if, in serving his prince, he can devote his life; if, in his intercourse with his friends, his words are sincere: although men say that he has not learned, I will certainly say that he has. ${ }^{75}$

Van Hoorn's verse translation:

When you learn and follow the trail of the wise men

And remain constantly focused in this study

Overcoming all difficulties through practice,

This will be of benefit to you and make you beloved;

Yea if you want to obtain wisdom from hard work

Then you can expect friends and companions

Even chosen from faraway countries and honoured

To be taught by you in the education of wisdom.

... When someone is so devoted to men

Of piety and virtue - just like the senses desire and love

Something that brings beauty and sweet delight -

And also devotes all his power, without diminishing it,

To obeying his parents with all due respect,

And does not spare his own life for his country or prince,

And has learnt faith and truth in his words,

Then I think he has studied enough. ${ }^{76}$

75 James Legge, The Chinese Classics. With a translation, critical and exegetical notes, Prolegomena, and Copious indexes (Taipei: SMC Publishing, 1991), p. 116.

76 'Indien ghy leert en volgdt het spoor der Wyse Mannen,

En in die study blyft volstandigh in gespannen,

En alle moeylyckheydt door oeffeningh overwindt,

Dat sal u kost'lyck zyn, en maecken wel bewindt;

Ia als ghy Wysheydt door beneerstingh wilt betrachten,

Soo hebt ghy mede maets en vrienden te verwachten,

Van verre Landen zelfs gesocht en oock vereerdt,

Om Wysheydts onderwys van u te zyn geleerdt, ...

Soo ymandt sich bevindt tot vroom en wijse Menschen,

Soodanigh toegedaen, gelyck de sinnen wenschen,

En minnen't geen dat mooy, en soet vermaeck toe-brenght,

En voorts geheele kracht besteedt en geensints krenckt, 
The original Latin now translated into Meynard's English follow:

Confucius asked: 'Will it not be a pleasure to strive to imitate the wise and to train constantly oneself in this effort of imitation? ... After you have successfully cultivated yourself with this kind of effort and perseverance, then followers and friends will come from afar in order to consult you and to transmit your teaching' ... The disciple, Zixia, ${ }^{77}$ says: 'If someone is delighted by honest and wise people, changing and transferring into them his love for things which are beautiful and agreeable to see - this means that a youth should desire virtue and wisdom with the same ardour and intensity of sensual love, since this period of life is usually controlled by the pleasure of the senses [my emphasis]; similarly, if he is resolute in fulfilling his duty as an honest son toward his father and mother, exhausting all his energy; moreover, if he is resolute in fulfilling his duties as a subject toward his ruler or prince, not hesitating to risk his own person and life whenever needed; finally, if he makes promises to comrades and friends with whom he has good relationships, always keeping his promises with a shining trust and truthfulness; whoever is like this, even though some may say that he has not yet studied, I myself shall always say that he had studied. ${ }^{78}$

It is not difficult to see that both the Dutch and Latin translations were (in some measure) faithful to the original Chinese, even though the Dutch verse text demonstrates more poetic license. Van Hoorn's translation also omits all proper names, which would have provided clues to the translator's knowledge of the Latin version. Yet the fragments quoted here contain an indication that the Dutch version may have been concerned with the original Chinese. For example, Van Hoorn's translation does not include the italicised sentence in the passage quoted above that, in fact, was not in the Chinese original. Meynard therefore concludes that this was a Jesuit addition on the basis of Western moral literature. ${ }^{79}$

Om ouders volle plichts gehoorsaemheydt te geven, Oock voor syn Landt of prins niet spaert syn eygen leven,

En in syn woorden trouw en waerheydt heeft geleert, Die houd'ick dat genoegh en wel heeft gestudeert', in Van Hoorn, Eenige voorname eygenschappen van de ware deugdt, p. 16.

77 In the Latin edition this name is transliterated as çù hia, Meynard, The Jesuit reading of Confucius, p. 104.

78 Meynard, The Jesuit reading of Confucius, pp. 97-105.

79 Meynard, The Jesuit reading of Confucius, pp. 97-105. 
Pieter van Hoorn would not have translated the original Chinese text directly; among Europeans, only a handful of Jesuit missionaries had mastered that skill. Yet, by the time his text was printed, Van Hoorn had lived for over a decade among a Chinese community of traders, craftsmen, and labourers who were permitted to reside within the walled city of Batavia. 'The whole upkeep of Batavia depends on the Chinese' noted a Dutch minister in 1625, 'because without them there would be no markets held here, and no houses, no works would be built'.80 By the end of the century, the number of Chinese (almost 3,700) was more than twice that of Europeans. ${ }^{81}$ Historians have thus portrayed Batavia as a de facto 'Chinese town under Dutch protection ... a cornerstone of the Chinese trade network in Southeast Asia'.82

Although most of the Batavian Chinese would have been illiterate, those who could read and write would have learnt to do so on the basis of the Confucian texts. This seems to have inspired yet another Dutchman to make, with the help of a schoolmaster trained in Macao, a word-for-word translation of the first chapters of the Analects into Latin. A copy of this text by Calvinist minister Justus Heurnius, complete with the Chinese characters and phonetic transcriptions, was sent to his brother Otto in Leiden. Heurnius attached a number of Christian works translated into Mandarin, such as a narrative on the Ten Commandments and a Dutch-Latin-Chinese dictionary ${ }^{83}$ Although he adopted some of the religious terminology coined by the Jesuits, Heurnius's texts were clearly intended for a Protestant context, in which trade

8o Justus Heurnius to the directors of the Amsterdam chamber of the voc, 29 January 1625. See Jacob Grothe, Archief voor de geschiedenis der oude Hollandsche zending (Utrecht: Van Bentum, 189o-1891), vol. 5, pp. 226-227.

81 In 1699, the population inside the walls consisted of 3,679 Chinese, 2,407 freed slaves, 1,783 Europeans, 670 people of mixed race, and 867 classified as 'other', according to a population census, Blussé, Strange company, p. 84.

82 Blussé, Strange company, p. 74. For more demographic details, see Marie-Sybille de Vienne, Les Chinois en Insulinde. Échanges et sociétés marchandes au XVII siècle, d'après les sources de la V.O.C. (Paris: Indes Savantes, 2008), pp. 219-227.

83 Compendium Doctrinae Christianae (Batavia: 1628), Leiden University Library, Special Collections, Acad. 225. It was probably sent by Justus Heurnius (Batavia) to Otto Heurnius (Leiden) in 1629. The bundle contains Confucii doctrina moralis, containing $5 / 6$ of chapter 1 of the Analects (fol. 11v-14v) and 'Colloquium Confucii cum puero' (i.e., the text and translation of Xiao'er lun, a discussion with the seven-year-old Xiang Tuo, during which Confucius is outwitted), fol. 6r-11r. On the dictionary (Acad. 224) and compendium (with copies in London and Oxford that contain a longer excerpt from the Analects) see Koos Kuiper, 'The earliest monument of Dutch Sinological studies. Justus Heurnius's manuscript Dutch-Chinese dictionary and Chinese-Latin compendium Doctrinae Christianae (Batavia 1628)', Quaerendo, 35 (2005), pp. 95-186. 
was paramount. ${ }^{84}$ For instance, the bundle of translations began with a set of 'expressions for buying and selling' Chinese goods such as silk and porcelain. Heurnius also wrote that his efforts would 'be of great usefulness to posterity, as soon as the Chinese trade is opened, as we hope. ${ }^{85}$

Did Pieter van Hoorn's translation of Confucius, and Johan van Hoorn's translation and interpretation of the Five Virtues (outlined below) fit a similar pattern: were they assisted by the Chinese in Batavia? As member of the Council of the Indies, Van Hoorn must have had frequent contact with this Chinese majority, depending on Chinese interpreters for business transactions as well as for more culturally inclined translations. A number of materials from his family archive, now held at the National Archives in The Hague, indeed attests to such intercultural exchanges. ${ }^{86}$ We find, for example, various papers relate to the Five Constants Wuchang 五常 of Confucian ethics, and their translation and explanation in Dutch. Dated 1694, these documents demonstrate the continuing interactions between the Van Hoorn family and the Chinese interlocutors of Batavia: interactions within which Chinese virtues remained of the greatest interest.

The first of these documents consists of two pages of Chinese paper describing the Five Constant Virtues of Confucius with a commentary and elaboration, written in a Chinese hand. The Five Constants of Confucius encompass the promotion of virtue through Ren (仁 benevolence, humaneness), Yi (義 righteousness or justice), Li (禮 proper rite), Zhi (智 knowledge), and Xin (信 integrity).

This Chinese manuscript, explaining the main virtues of Confucius, is directly related to a document, this time on European paper and in a European hand, concentrating on the same concepts of Ren, Yi, Li, Zhi, and Xin. Most likely, the European writer based this project directly on the available Chinese example. The 'calligraphed' virtues are surrounded by a translation in Latin, together with the rather awkwardly phrased 'Nosse: Ex: Propinqvo: Solidae: Virtutis: Est:', or 'It is to have been known from nearness of solid virtue'. Here,

84 Heurnius, as 'the first Protestant missionary to be confronted with this difficulty', adopted the Jesuits' usage of the Chinese term Tianzhu (Lord of Heaven) to denote the Christian God; the terminology must have been suggested by the schoolmaster who had been trained in Macao, a centre of Jesuit learning. Duyvendak, 'Early Chinese studies in Holland', p. 321, who also notes that the inclusion of the Ten Commandments signals Heurnius's Protestant focus.

85 Justus Heurnius to the directors of the Amsterdam chamber of the voc, 29 January 1625. See Grothe, Archief voor de geschiedenis, pp. 226-227.

86 Nationaal Archief, Den Haag, Collectie Van Hoorn-Van Riebeeck access 1.10.45, inventories 2-14. 


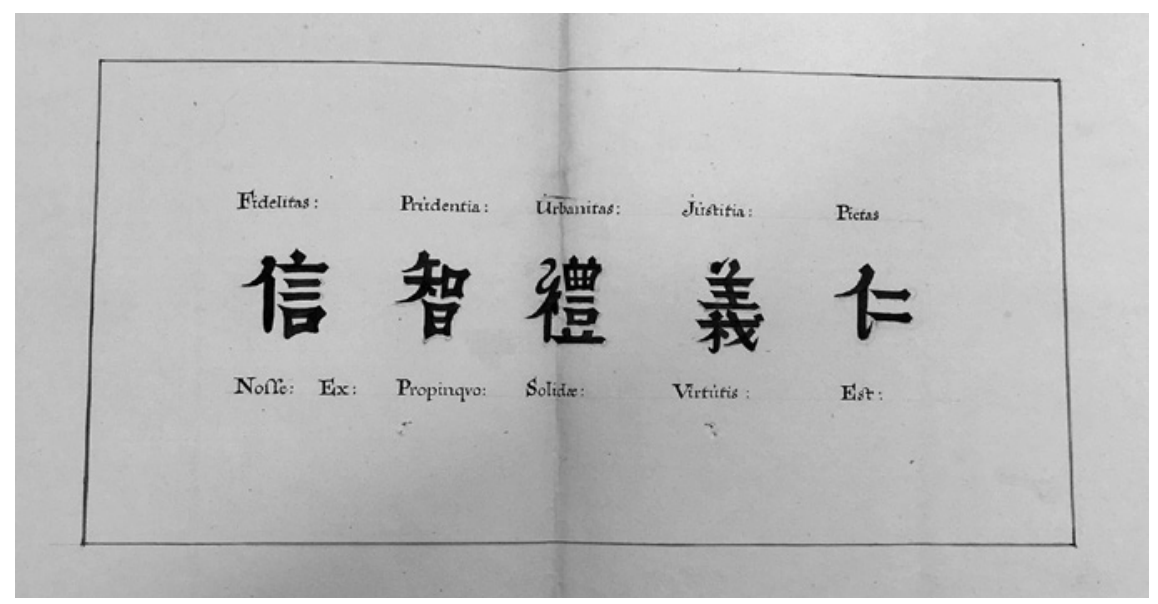

FIGURE 25 Chinese virtues, in the Van Hoorn Archives National Archives The Hague, Collection Van Hoorn Riebeeck 1.10.45, no. 3

Ren is translated as pietas, Yi as justitia, Li as urbanitas, Zhi as prudentia, and Xin as fidelitas.

This type of comparison between the virtues of China and Europe began with the Jesuits. When Matteo Ricci came to China, he soon identified the Five Constants, showing great admiration for Li and Zhi specifically: 'This ancient empire is worldly known and its people are polite and abide by codes of conduct. Li is one of the five most precious virtues in this land. ${ }^{87}$ For Ricci, the main purpose of Confucian ethics was to establish a stable and harmonious nation, economical safety for families, and morally cultivated individuals was 'compatible with the brightness of conscience and the truth of Christianity'. This Jesuit understanding of Chinese virtues was elaborated further by subsequent Jesuit translators. For instance, the Jesuits had long interpreted Ren as 'true virtue of the heart', 'the inner, real, and perfect virtue', or 'charity and piety': charitas et pietas. ${ }^{88}$ In the first part of Confucius Sinarum philosophus, Ren is indeed translated as pietas, as it was in Sapientia Sinica and Politico-moralis. ${ }^{89}$ Likewise, both Van Hoorn and the Jesuits understood Yi as justitia, Zhi as prudentia, and Xin as fidelitas. The only aberrant translation was that of Li. The Jesuits understood the concept as civilitas, while Van Hoorn translated it as urbanitas. However, both terms could be understood as 'civility' or the Dutch

87 Matteo Ricci and Nicolas Trigault, Matteo Ricci's reading notes about China (Beijing: Zhonghua Publishing House, 2010), p. 63.

88 Meynard, The Jesuit reading of Confucius, p. 101.

89 Meynard, The Jesuit reading of Confucius, p. 64. 
heuscheydt, meaning the just exercise of tolerance, respect, and consideration towards fellow social participants or fellow citizens. ${ }^{90}$

While the Jesuit interpretation of the Five Constants of Confucius certainly influenced the Van Hoorn translation of the same, another document does hint at a more direct Chinese reading. In an accompanying note, Johan van Hoorn requests Johannes Melman to translate the Chinese text into Dutch:

\author{
Gui ij: Li Thi Sin \\ Chinese sinspreuken \\ Beduijdinge off begrip der \\ Chinese sinspreucken \\ Gui Iji. Li Ti. Sin \\ In 5 printen mij toegebragt
}

\begin{abstract}
Monsr. R. melman
Ik sal bij occagie van uE; beleeftheijt

verwagten of $\mathrm{uE:}$ mij wilde teregthelpen

met de vertalinge uijt het Chinees

vande beduijdenis desen 5 . Sinspreuken

5 Julij 1694

Uedgnt

$\mathrm{JvH}^{91}$
\end{abstract}

Johannes Melman had been the official translator of the second Dutch embassy. Indeed, he is regularly mentioned in Olfert Dapper's account of the embassy: 'Lieutenant Hendrik van Dalen [sent] the translator Johannes Melman to Tanganpek to find out the cause, reason and the why'. ${ }^{92}$ Melman is also referenced by Nicolaas Witsen in the second edition of his Noord en Oost Tartarye, again emphasising the interpreter's skill in Chinese: 'Johannes Melman, who already has been in China as translator in service of the Dutch company since 1656 , and afterwards travelled there many times as merchant, knew the

9o François A. Pomey, Novum dictionarium Belgico-Latinum (Maastricht: Lambert Bertus, 1729); Barbara Cassin (ed.), Dictionary of untranslatables. A philosophical lexicon (Princeton and Oxford: Princeton University Press, 2004), p. 139.

91 'Gui ij Li Sin, Chinese aphorisms, meaning or concept of the, Chinese aphorisms, Gui ij Li Thi Sin, handed to me in five prints. Mister Melman, I will anticipate when you have the opportunity, your discretion in helping me out with the translation from the Chinese of the meaning of these five aphorisms, Yours, 5 July 1694 JvH', in NA 1.10.45 (11).

92 'Luitenant Hendrik van Dalen [zond] den tolk Johannes Melman na Tonganpek, om d'oorzake, waerom en ten welken einde af te vragen?' in Dapper, Gedenckwaerdig bedryf, p. 13o. See also p. 79 , p. 118, pp. 372-373, p. 376 . 
language well, as he heard it many times in Beijing, and in other places in China, as spoken by the most erudite Tartars. ${ }^{93}$

Indeed, Melman did produce the translation, which is also held in the archive, assisted by two Chinese people: Vertaling van vijfChineesse boekjes, die de naam dragen van Singli (wijse redenen uijt het hert voortkomende) overgeset volgens de vertolking der Chineesen Sjauwgoanko en Limphoanko ('Translation of five Chinese booklets, that bear the name of Singli [sage reasons taken from the heart] transcribed according to a translation by the Chinese Sjauwgoanko and Limphoanko').94 The translation follows the Chinese example relatively conscientiously in that it renders the same parables, allegories, and semi-historical stories. Each virtue is accompanied by a short biography, serving as an example of one of the Five Constants. For example, Zhi or prudence is linked to Zhuge Liang 諸葛亮: a Chinese politician, military strategist, writer and engineer of the Shu Han 蜀漢 during the Three Kingdoms (Sanguo) 三國 period of the second century CE..$^{95}$

Another document from the Van Hoorn family archives illuminates yet another layer of transtextual transmission. With the translation by Johannes Melman in hand, another Dutchman, probably not Johan van Hoorn as the handwriting does not match, wrote an uitlegginge or an interpretation and meaning of the five Chinese aphorisms or main virtues, as described by the Chinese philosopher Confutius, for his disciples, and explained with examples. ${ }^{\prime 6}$ The text explains how the Chinese virtues should be understood within a European context, with ample comparison with European virtues:

The first maxim Gin, which among other things stands for piety, love, respectfulness and compassion, means in the Chinese language to love

93 'Johannes Melman, die al in den Jare 1656 zich in Sina, ten dienste der Nederlandsche Maetschappy, als Tolk opgehouden heeft, en namaels steeds als Koopman meermalen aldaer geweest is, en der Taele zeer kundig was, voor zoo veel als hy zulks in Peking, en elders in Sina, uit den mond der eigene meest verstandigste Tartaren', in Nicolaas Witsen, Noord en Oost Tartarye, ofte bondig ontwerp van eenige dier landen en volken (Amsterdam: François Halma, 1702), p. 20. Witsen subsequently cites a letter from Melman dated 4 December 1692.

94 'Translation of five Chinese booklets, that bear the name of Singli (sage matters from the heart) translated by the Chinese Sjauwgoanko and Limphoanko', in NA 1.10.45 (11).

95 Ren or pieta was identified with Tangju Qing 唐聚慶, righteousness or Yi with Guan Zhong 管仲 and Bao Shuya 鮑叔牙, propriety or Li with Qiu Zhongni 丘仲尼, and fidelity or Xin with Zhang Shi 張式 en Fan Juqing 范巨卿.

96 'Beduydenisse van de vijff chinese zin-Spreucken off hoofftdeugden, bij den chinese wijsgeerigen confutius, aen sijne leerlingen beschreven ende met exempelen voorgestelt', in NA 1.10.45 (11). 
someone rightly, with respect to God's laws, to not place yourself above others, to be elegant and respectful in conversation, to comfort the downtrodden, to have a heart full of compassion and charity, to show affection to all people, to help your parents in their humility and in matters of health, to help them in sickness as long as they live, and to provide them with decent funeral processions after their death. This argument is confirmed by the example of a certain sage named Petoo [probably Tangju Qing], who lived an irreproachable and holy life, honouring God and fulfilling his pious tasks in their temple. ${ }^{97}$

Johan van Hoorn's engagement with Chinese writings did not end there. Around 1700, the Governor General received an image of an inscribed Chinese mirror from the Amsterdam burgomaster Nicolaas Witsen. The mayor's learned network, which included missionary scholars in Rome and Paris, had been unable to translate the mirror's ancient inscription; so, he asked Van Hoorn to consult his Chinese community. Van Hoorn asked an 'interpreter in Batavia', but nobody could fully decipher the mirror's ancient seal script. ${ }^{98} \mathrm{He}$ therefore had the request forwarded to more literate Chinese on the mainland, possibly in Guangzhou, a town that had relatively common trade dealings with Batavia. ${ }^{99}$

In 1705, Witsen recounted how he had 'sent [the image of] the mirror to Batavia where more than ten thousand Chinese live. No one understands it, but the Governor General had it brought to China to show to learned Chinese, asking them for an explanation, and so it happened.' ${ }^{100}$ The 'learned Chinese'

97 'De eerste Zin-spreucke Gin; die onder andere genomen leert, voor godtvrucht, liefde, eerbiedigheijt ende mededogentheijt, betekene in de chinese spraake, ymand onder de vreese gods wel te beminnen, zig zelven boven andere niet te verheffen; bespraacksam te zijn, bedruckten te troosten, een herte vol deernis ende barmhaertigheijt te hebben, genegentheijt aen eener ygelyken te betoonen; zijne ouders in verlegentheijt bijstant te doen, ende die te helpen in gesontheijt, daerover toesigt te nemen in sieckte, die te helpen soo langs die leven, ende hun dere van lyckstatien aen te doen, na hunne doot. Dit argument wort met een exempel bevestigt; hoe dat seker wijsgeerige petoo genaemt, die aldaar een onberispelijk ende heijlig leven vaerde, ende onder got eren nemen van sijne godtvrucgtige plichten, in hare tempel', in NA 1.10.45 (11).

98 '[D]e uytlegger van dese mijne spiegel op Batavia', Nicolaas Witsen to Gijsbrecht Cuper, 20 October 1705, J. Gebhard, Het leven van Mr. Nicolaes Cornelisz. Witsen (vol. 2, Utrecht: Leeflang, 1881-1882), no. 21, p. 307.

99 The voc did not establish a trading post until 1729, but earlier vrijburgers (free citizens) from Batavia were trading regularly with Guangzhou, a centre of arts and crafts production. See Hertroijs, 'Hoe kennis van China naar Europa kwam', p. 102.

100 '[I]k sont het dan na Batavia alwaer meer als tiendusent Sinesen sijn, nimant verstaet het, dog de generael dede het overbrengen na Sina om aen geleerde Sinesen te vertonen, 
transcribed the ancient seal script into contemporary characters; the Dutch translation that followed was incorrect but certainly made an attempt at accuracy. Incidentally, a faulty transcription of a single character resulted in the poem being read as a monotheistic paean, which fitted Witsen's argument that the ancient Chinese had once been similar to Christians. ${ }^{101} \mathrm{He}$ concluded that his mirror dated to the time of Confucius: 'It is remarkable that these letters are more than a thousand years old and the common man cannot read them at all. This is a device or symbol from ... around the time of the very learned and pious Confucius of whom was said, with more reason than was said once about Plato and Seneca, "O Saint Confucius".'102 Witsen's translation only survives in Dutch, but there may have been other languages involved in the process of translation, such as Malay or Portuguese. ${ }^{103}$ In any event, this exchange proves again that Chinese-Dutch collaboration on translating sophisticated Chinese texts was possible.

Until late in his career, Johan van Hoorn maintained many connections to Chinese civilisation when fashioning his professional identity. At the tender age of 12, he had been appointed a junior voc official to accompany his father on the 1665 embassy to Beijing. Due to his 'intimate as well as business-like' contacts with the Chinese in Batavia, he became the richest man in the Indies. ${ }^{104}$ When, after spending 30 years in Asia, he returned to the Netherlands, he filled his Amsterdam mansion with staggering amounts of high-quality Asian, specifically Chinese, arts and crafts. His inventory included porcelain (570 sets of cups and saucers), furniture, and lacquerware. Some of these objects were customised for his children with the family's coat of arms: a material expression of the manner in which three generations managed to negotiate the melting pot of cultures that Batavia was. ${ }^{105}$

en die explicatie te versoeken, so als geschiede', Nicolaas Witsen to Gijsbrecht Cuper, 20 November 1705, in Gebhard, Het leven van Mr. Nicolaes Witsen, no. 22, pp. 308-309.

101 Willemijn van Noord and Thijs Weststeijn, 'The global trajectory of Nicolaas Witsen's Chinese mirror', Rijksmuseum Bulletin, 4 (2015), pp. 325-361.

102 'Het is bijsonder dese letters syn al over de duysent jaer verout, en de gemene man kan se gants niet lesen, het is een devies (symbolium) van ... omtrent de tijt van de so geleerde en vrome Confutius, van wien men met meer reden als eertijds een ander van Plato en Seneca uytriep, O Heylige Confutius, Nicolaas Witsen to Gijsbrecht Cuper, 20 October 1705', in Gebhard, Het leven van Mr. Nicolaes Witsen, p. 307.

103 Kuiper, 'The earliest monument of Dutch sinological studies', p. 112.

104 Blussé, 'Doctor at sea', p. 16; Kees Zandvliet, De 5oo rijksten van de Republiek (Zutphen: Walburg Pers, 2018), pp. 144-145.

105 Jan van Campen, 'The hybrid world of Batavia', in Jan van Campen, Femke Diercks and Karina Corrigan (eds.), Asia in Amsterdam. The culture of luxury in the Golden Age (Amsterdam: Rijksmuseum, 2015), p. 47; Johan van Hoorn inventory, notary Michiel 
The Confucian translation and the interpretation of the Five Constants may have been similarly a 'customised' piece of Chinese civilisation to express the family's identity with Asia. Van Hoorn senior presented the text to his 'dear wife and children', calling it 'something beautiful that I have brought you from China and, if you use it well, this will be better than if I had carried large treasures from that country.'106 The family's intimate relationship with the Chinese comes into even closer proximity in documents relating to the family's return to the Netherlands in 1709. Johan van Hoorn, now of ailing health, was accompanied by a Chinese medical doctor by the name of Zhou Meiye 周美爺. $\mathrm{He}$ seems to have been a personal friend, who could 'read and write everything in Chinese' while also being able to speak Dutch. ${ }^{107}$ During the long journey, the doctor held forth about the three Chinese 'sects' of Confucianism, Taoism, and Buddhism and explained to the Governor General the capital virtues outlined by 'the Chinese sage Confucius'. ${ }^{108}$ Was it perhaps Dr. Zhou who helped interpret the Chinese virtues for Johan van Hoorn? In any case, the Chinese doctor did not stay long in the Netherlands: after only six weeks in Amsterdam, he took the first ship back to China.

\section{4 The 1687 Jesuit Edition of Confucius in Latin}

After Van Hoorn's book, it would take 12 more years for the Latin translation to appear. In 1683, Philippe Couplet, travelling on a Dutch ship, arrived in Enkhuizen to advertise the Jesuit mission on a European tour. He brought with him 400 Chinese Christian books donated by a converted noblewoman. He was also accompanied by a young Chinese man, Michael Shen Fuzong: the son

Servaas, Amsterdam City Archives, notarial archives, inv. no. 50o6, no. 15, 20 October 1711. See also Bea Brommer, To my dear Pieternelletje. Grandfather and granddaughter in VOC time, 1710-1720 (Leiden: Brill, 2015).

106 'Ontfangt dit dan waerde Huys-Vrouw en Kinderen als wat mooys dat ick uyt China Voor ue: heb mede gebracht, en soo ghij het $\mathrm{U}$ te nutte kunt maken, dat sal beter zyn als dat ick U groote Schatten van daer toe-gebracht hadde', in Van Hoorn, Eenige voorname eygenschappen, p. 4.

107 'Dien Sinesen Heer konde alles lesen, en schrijven, dat Sinees was', Nicolaas Witsen to Gijsbrecht Cuper, 5 December 1710', in Gebhard, Het leven van Mr. Nicolaes Witsen, pp. 332335. François Valentijn, Oud en Nieuw Oost-Indien (vol. 2, Dordrecht and Amsterdam: Joannes van Braam and Gerard onder de Linden, 1724-1726), p. 254.

108 'Den Chineesen leermeester Confutius', in Archival documents 'Aantekeningen van de Chinese arts Thebitia' are kept in the KITLV library, Leiden, dh 269. Quoted from Blussé, 'Doctor at sea', p. 21. 
of Christian converts from Nanjing. ${ }^{109}$ Thoroughly educated in the Confucian texts, Shen Fuzong was able to assist with the publication of Confucius Sinarum philosophus, which was intended to include Chinese characters. ${ }^{110}$ Copies of the Chinese editions of Confucius with Shen's Latin annotations remain in the Bodleian Library in Oxford. ${ }^{111}$

During their lengthy stay in the Dutch Republic, Couplet and Shen worked on an introduction to the book and, in the meantime, it seems, discussed the matter with local scholars. ${ }^{112}$ However, this time Blaeu or another Dutch publisher would not be an option. Instead, they looked to Paris where Melchisédech Thévenot, by then royal librarian, managed to acquire printing permission and financial support from Louis XIV. In August 1686, Couplet began sending his manuscripts to Paris, where he himself arrived six months later. On 29 April 1687, the royal censor granted permission to publish. The honour fell to Daniel Horthemels of the Rue St. Jacques: a Dutchman who had only recently converted to Catholicism. Horthemels arrived in Paris in 1686 from Middelburg in Zeeland by way of Charenton in northern France. His brother, Gillis, remained in Zeeland. He maintained close contacts in the Northern Netherlands, among them, Kircher's publisher Johannes Janssonius van Waesberge. ${ }^{113}$ Together with his father-in-law, Horthemels belonged to a group of select printers who aimed primarily at the foreign market. ${ }^{114}$

Printing, carried out by Andreas Cramoisy, was finished within a month. The book did not include the Chinese characters that Couplet had envisaged, even though the notation numbers for these had already been set in type in the first few chapters. ${ }^{115}$ Initially, the Latin text was intended to be accompanied

109 The noblewoman was Candida Xu. See Phillipe Couplet, Historie van eene groote, christene mevrouwe van China met naeme mevrouw Candida Hiu ... beschreven door ... Philippus Couplet ... ende in onse Nederlandtsche taele door H.I.D.N.W.P. overgheset (Antwerp: Franciscus Muller, 1694).

110 Theodore Foss, 'The European sojourn of Philippe Couplet and Michael Shen Fuzong, 1683-1692', in Jerome Heyndrickx (ed.), Philippe Couplet, S.J. (1623-1693). The man who brought China to Europe (Nettetal: Steyler Verslag, 199o), pp. 121-142.

111 Oxford: Bodleian Library, Sinica 2.

112 Meynard, Confucius Sinarum philosophus, p. 10.

113 Van Eeghen, De Amsterdamse boekhandel, vol. IV, p. 159, p. 186.

114 Van Eeghen, De Amsterdamse boekhandel, vol. V1, p. 87.

115 'Lettergieterye, waer in gegooten werden alle soorten van Letter ... ook in 't Chinees, Japonees, en verdere Oosterse Talen', in 's Gravenhaegse courant, The Hague, 18 February 1729, p. 4. I am indebted to John A. Lane for providing this information. Also see Knud Lundbaek, The traditional history of Chinese script (Aarhus: Aarhus University Press, 1988), p. 45; According to Golvers, 'The development of the Confucius Sinarum philosophus', p. 116o, the choice of Horthemels (who had abjured Calvinism only in 1686) was inspired by Couplet being 'attracted to his Flemish-Dutch countrymen'. 


\title{
CONFUCIUS
}

\section{S I N A R U M}

\section{PHILOSOPHUS,}

\section{S I V E}

\section{S C I E N T I A S I N E NSIS}

\author{
L A T I NE EXPOSIT A.
}

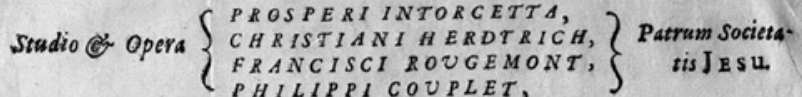

J O S S U

\section{LUDOVICI MAG N I}

Eximio Miffontom Orientalium os Litterarie Reipublice bono

E BIBLIOTHECA REGIA IN LUCEM PRODIT.

ADJECTA EST TABULA CHRONOLOGICA SINICA MONARCHIA AB HUYUS EXORDLOAD HAC US QUE TEMPORA
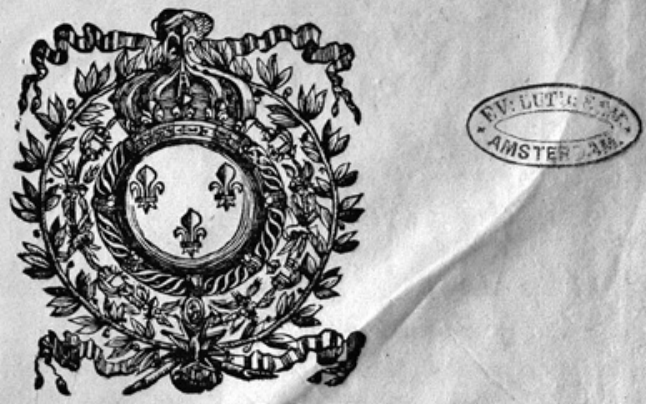

P A R I S I I S,
Apud DANIELEM HORTHEMELS, viâ Jacobæà, fub Mrecenate.

CVMPRIVILEGIO REGIS.

FIgure 26 Philippe Couplet et al., Confucius Sinarum Philosophus (Paris: Daniel Horthemels, 1687) Allard Pierson Amsterdam (K 61-272) 
by the main terms in Chinese. However, at this time it remained costly and impractical for printers to found Chinese type. All Chinese characters in seventeenth-century European publications were therefore made in either woodcut or engraving. It would be well into the eighteenth century before Chinese leaden type could be produced; although, in 1729, a printer from The Hague advertised his 'type-foundry, where every type of letter is cast ... also in Chinese, Japanese, and other Eastern languages', there is no evidence to show that he ever produced such type.

The publisher's paratext communicates from the outset that this was not a work intended for the masses. The material construction of the book (or its bibliology) - size, title page, use of paper, and typesetting - all indicate that its potential audience consisted of a rather small group of wealthy and presumably educated readers. There are various indicators for such a peritextual reading of the material qualities of Confucius Sinarum philosophus. The book was printed on paper of very highly quality, in an expensive folio size that, in this period, was mainly reserved for serious works of religion or philosophy. This extensive use of the very precious commodity of paper, which made up the bulk of production costs, communicated to the public that this was a work worthy of their time and money.

The same sentiment is echoed throughout the book. The publisher took great care in the material construction of Confucius Sinarum philosophus, and his publishing strategies become clear when taking all the elements of bibliology into consideration. Until the invention of the printed cover, the title page was the first thing potential buyers would encounter; since publishers provided no cover at all, it would be made by a different artisan and only at the request of the buyer, who had to pay for it separately. Usually, the cover would bear no specific text. This means that the title page was intended as the first point of information, as well as an important opportunity for advertisement on part of the publisher. In the case of Confucius Sinarum philosophus, the title page is a veritable summary of everything the reader could expect inside. It communicates that this is a book about a Chinese philosopher named Confucius, and that the teachings of this sage are presented in Latin. The names of the translators are provided, indicating that they belonged to the Society of Jesus. The work is dedicated to Louis XIV, who in his infinite wisdom has now provided the world at large with this translation by lending his considerable support to the Jesuit missionaries. Visual elements on the title page underline these points; for example, the use of blank space and the inclusion of the Jesuit ornament IHs. The title page conveys the message that this book contains rare and specialised knowledge, with official royal support. 
Even though they are perhaps most conspicuous, format and title page are not the only forms of publisher's peritext that influenced the material realisation of a book. In the context of a paratextual analysis of Confucius Sinarum philosophus, typography, the choices of typeface and the arrangement of this type on the page, and the quality of paper should also be considered. Choices related to typography may provide by their very existence an indirect commentary on the text, affecting its potential reading. In this case, the use of blank space or, in the words of poet Paul Éluard, 'grandes marges blanches de silence' was particularly telling. ${ }^{116}$ No reader could be indifferent to its use (or lack thereof), especially since it communicated a certain luxury, as the high cost of paper would often prohibit non-essential use.

When we come to examine the typography of Confucius Sinarum philosophus further, we find that it emphasises the luxurious and elitist character and intent of the book, evinced in the quality of paper used. Printing papers of the hand-press period were produced in various conditions, which were often offered in a choice of two or three different values: fine, second, and ordinary ( fin, moyen, and bull). ${ }^{117}$ The paper used in the printing of the Confucius translation was of the finest quality, which would lend an additional aesthetic and economic quality to the final product.

By their very existence, those elements of paratext that are part of the publisher's epitext (elements beyond the text) communicate certain values about the book to its potential audience. With Confucius Sinarum philosophus, publisher Horthemels, printer Cramoisy, and editor Couplet (who was indeed very much involved with the production) gave shape to every one of those elements that declared that this translation was intended for a wealthy and educated elite, who wished to own a work of such high importance that even the king of France would lend his support to its creation. Whether the actual audience would indeed receive this message remains, of course, unclear. There are very few ego documents available from this period, and probably none that reflect on their first impressions after seeing Confucius Sinarum philosophus in its full printed glory.

116 'Le poète est celui qui inspire bien plus que celui qui est inspiré. Les poèmes ont toujours de grandes marges blanches, de grandes marges blanches de silence où la mémoire ardente se consume pour recréer un délire sans passé. Leur principale qualité est non pas, je le répète, d'invoquer, mais d'inspirer. Tant de poèmes d'amour sans objet réuniront, un beau jour, des amants'. Paul Éluard, 'L'évidence poétique', in Oeuvres complètes (Paris: Gallimard, 1968), p. 515.

117 Gaskell, New introduction into bibliography, pp. 66-67. 
While the paratext gives valuable indications as to how the producers wished the potential readership to perceive the work, an examination of the actual text offers additional clues. In the preface, Couplet uses the Confucian classics to argue in favour of the Jesuit mission, a message which was aimed at the ecclesiastic authorities and political powers of Europe, as well as the Republic of Letters in general. To do this, Couplet placed Confucius in his historical context, emphasising how difficult this process had been due to the paucity of written records. Couplet then compared the translation of Chinese records with philological projects concerning the Greek and Latin classics, a familiar strategy among European humanists.

To give his work further credence, Couplet explained in the next chapter that the Jesuit translation is based on 'evidence drawn, not from the modern interpreters (Neo-Confucianism), but as much as possible, from the original texts'. These texts included additional Chinese commentators, highlighting how their interpretive work was confirmed by Chinese authorities. ${ }^{118}$ As such, Confucius Sinarum philosophus would present pure Chinese thinking. By framing the work as a philological project, Couplet not only appealed to prospective missionaries and ecclesiastical authorities, but also to the Republic of Letters at large. Through lexical means, Couplet was able to unveil those Christian elements in Chinese philosophy that would provide Confucius with a position similar to that of the Greek and Roman authorities. European humanists would have recognised this approach as it was similar to how pagan antiquity was incorporated into Christian scholarship. Confucius could thus be compared to the Hebrew prophets or even the pagan Sibyls (the female oracles of ancient Greece who preceded Moses). ${ }^{119}$

By fitting Confucius into a familiar humanistic framework that concerned both the search for the oldest textual sources and the quest for ancient wisdom, Couplet appealed to the intellectual European Republic of Letters. His most original contribution, however, was not the focus on proto-Christian elements in the teachings of Confucius, but in the Chineseness of these writings. During his visit to Europe, this latter focus was also emphasised; in the presence of Chinese assistants, among them Michael Shen Fuzong, Couplet arrived in the Dutch Republic with a cargo of Chinese books, which were gladly received by scholars such as Amsterdam burgomaster Nicolaas Witsen.

118 Meynard, Confucius Sinarum philosophus, p. 101.

119 Van Noord and Weststeijn, 'Nicolaas Witsen's Chinese mirror', pp. 345-347. 
Philippe Couplet's Confucius Sinarum philosophus (1687) was never fully translated or reprinted, implying that the influence of the work primarily emerged more through the circulation of intellectual content, than by any physical distribution of the work itself. However, within a year of publication, the more general (and less affluent) public could discover Confucius for themselves through two partial translations in French. ${ }^{120}$ The first was written by Frenchman Simon Foucher and was published in 1688 under the title, Lettre sur la morale de Confucius, philosophe de la Chine by Daniel Horthemels in Paris; the same publisher responsible for Confucius Sinarum philosophus. ${ }^{121}$ In the same year, Pierre Savouret of Amsterdam issued La morale de Confucius, philosophe de la Chine. ${ }^{122}$ According to the title page, the book was written by Jean de Labrune, yet definite authorship remains uncertain and I have been unable to find more information regarding the true author. ${ }^{123}$ Although the books originally appeared separately, they were often bound together and, from 1783 , were indeed published jointly.

Simon Foucher's translation was not a Dutch-made work, yet its existence and content are nevertheless related to La morale de Confucius. The Short Title Catalogue of the Netherlands considers Foucher's translation to be part of the Dutch canon by including it in its catalogue: publisher Pierre Savouret

120 The first translation of Confucius in a vernacular language had already appeared in 1685, from the pen of English non-conformist minister Nathaniel Vincent. However, the influence of this translation would have been negligible since it remained unnoticed until Matt Jenkinson rediscovered it as appendix to a court sermon in 2006. See Jenkinson, 'Nathanael Vincent and Confucius's "Great learning"', pp. 35-47.

121 Simon Foucher, Lettre sur la morale de Confucius, philosophe de la Chine (Paris: Daniel Horthemels, 1688).

122 [Anonymous], La morale de Confucius, philosophe de la Chine (Amsterdam: Pierre Savouret, 1688).

123 For the sake of convenience, I will refer to the Amsterdam edition by the name of Jean de Labrune. However, the authorship of the Amsterdam translation remains uncertain. People often assumed Simon Foucher to be the author, since the two translations were often bound together. However, a comparison shows the two books to be from different hands. Jacques Bernard (1658-1718), French theologian believed the author to be Protestant minister, Jean de Labrune. However, bibliographer Antoine Alexandre Barbier (1765-1825) noticed that the preface of La morale de Confucius was written from a Catholic viewpoint and not according to Protestant principles. Barbier then proposed Louis Cousin as the author, since he (as royal censor) had approved the publication of Foucher's La lettre sur la morale de Confucius. It was also Cousin who approved the publication of Confucius Sinarum philosophus. However, regardless of four centuries of speculation, the authorship of the Amsterdam translation remains uncertain. 
provided Lettre sur la morale with a 'Dutch' title page bearing his own name and address, and both translations were often bound together. ${ }^{124}$ It is likely that Savouret in Amsterdam and Horthemels in Paris were at least on a basic level in cooperation with regards to their respective publications. This collaboration would also explain why the works were often bound together: Savouret was presumably selling the Paris edition in his shop, while Horthemels would provide his Parisian clientele with the Amsterdam edition.

Simon Foucher and Jean de Labrune were the first to provide the European readership with a translation of Confucius in French. This was a significant occasion, marking the further interaction of Chinese and European culture. To quote Brenda Hosington's apt comment: 'Throughout history ... translation has always been a means by which knowledge was transmitted and cultural and spiritual values were exchanged between communities.' ${ }^{125}$ Translation is a complex and varied process of intertextuality, in which a text is often rewritten and manipulated 'to make [it] fit in with the dominant, or one of the dominant ideological and poetological currents of their times.' ${ }^{126}$ This statement is attested by Confucius Sinarum philosophus itself, which is, of course, a translation of various Chinese texts. We have already seen that the Jesuit translators indeed influenced the European reading of Confucius by conforming the text to the 'ideological currents' of their time and religion. ${ }^{127}$ Subsequently, Foucher and Labrune took Confucius and his teachings from its decidedly Jesuit and Latin context and introduced him into the French cultural field by way of translation.

Central to this development is how this act of transtextuality affected the form and content of these texts. This process was guided by the publishing strategies conceived by Horthemels in Paris and Savouret in Amsterdam. These strategies relate not only to a change in historical, geographical, and social context in which Confucius could now be read, but it also depends on

124 This was not an unusual practice, but occurred more often when the final product was the result of cooperation between a number of printers and publishers. Short Title Catalogue Netherlands, http://picarta.pica.nl/xslt/DB=3.11/XMLPRS=Y/PPN?PPN=317883275, last accessed 23 August 2021.

125 Brenda M. Hosington, 'Translation and print culture in early modern Europe', Renaissance studies, 29.1 (2015), pp. $5^{-18}$, p. 5 .

126 Andreé Lefevre, Translation, rewriting, and the manipulation of literary fame (New York: Routledge, 1992), p. 6.

127 On the translation of Confucius Sinarum philosophus see previous section. Meynard, The Jesuit reading of Confucius; Meynard, Confucius Sinarum philosophus; Peter Burke, 'Cultures of translation in early modern Europe', in Peter Burke and Ronnie Po-Chia Hsia (eds.), Cultural translation in early modern Europe (Cambridge: Cambridge University Press, 2007), pp. 7-38, pp. 9-11. 
the changing nature, location, and social status of the potential readership. ${ }^{128}$ As will be further discussed below, the representation of Confucius in the French translations was less part of a religious debate on the Jesuit interpretation of Chinese religion and philosophy, and more concerned with emphasising how this Chinese sage may provide insights into morality and virtue in more general terms. ${ }^{129}$ A further difference between Confucius Sinarum philosophus and its translations in French has to do with the form of publication and the way in which the peritext influenced audiences and their interpretations. As discussed earlier in this chapter, Confucius Sinarum philosophus was an expensive work, of which its bibliology, or the book's material construction, indicated that its potential audience consisted of a rather small readership of wealthy and presumably educated buyers. In contrast, the materialisation of the translations by Foucher and Labrune imply a much broader dispersion. Publishing strategies made visible through processes of transtextuality greatly influenced both form and content of the French translations of Confucius Sinarum philosophus. To quote Umberto Eco: 'Translation is always a shift not between two languages but between two cultures'. In this process, Foucher and Labrune, helped by their publishers Horthemels and Savouret, turned the teachings of Confucius into something decidedly more secular than the Jesuits had ever intended. 130

Born in Dijon, Simon Foucher was educated at the Sorbonne. Later in life, he became a canon of the Dijon Cathedral, even though he primarily spent his life in Paris. This may have been the reason why, with his translation of Confucius, Foucher had infused himself into a fundamental debate on how to reconcile Jesuit conclusions regarding Confucius's atheism with admiring accounts of the virtue of the Chinese sage. ${ }^{131}$ This debate had begun in 1616 , when Matteo Ricci and Nicolas Trigault described those following the teachings of Confucius as worshipping 'one sole God'. However, Trigault had already noted that, without the guidance of the true faith, 'there are a few of them who,

128 Hosington, 'Translation and print culture', p. 9.

129 A. Owen Aldridge, The dragon and the eagle. The presence of China in the American Enlightenment (Detroit: Wayne State University Press, 1993), p. 25; Pinot, La Chine et la formation de l'esprit philosophique en France, p. 375; Alan Charles Kors, Atheism in France, 1650-1729. The orthodox sources of disbelief (Princeton: Princeton University Press, 1990), pp. $76-77$, p. 164 .

130 In his article on translating in early modern Europe, Peter Burke draws the parallel between the work of a translator and that of a missionary by showing that missionaries such as Matteo Ricci may have translated religious texts as a means of conversion, but that they themselves often found themselves translating their own religion as well, 'in the sense of adapting it to the local culture'.

131 Kors, Atheism in France, p. 164. 
from much greater descent, fell into atheism'. Since China was divided into so many sects, the Chinese were becoming more and more irreligious, with some embracing 'the very grave errors of atheism'. Confucius Sinarum philosophus was meant to settle the issues of Chinese atheism and, of course, defend the Jesuits' accommodating practice of intermingling Confucian and Christian terms and rituals. Couplet insisted that Ricci and Trigault were confused by the superstitious elements of a later form of Confucianism that had been 'infected by Buddhism.' ${ }^{132}$

To be sure, for Couplet, the teachings of Confucius only demonstrated the purest theism. He noted that atheism did exist in China, but only within Buddhism. Confucian tradition and Chinese scientific heritage made it evident that the Middle Kingdom had taught the true God two millennia years before Christ, and their virtue was no mere 'external appearance', but a sincere internal virtue, which showed itself in 'seriousness, modesty, continence, abstinence and decorum. ${ }^{133}$ As atheism could never be virtuous, it followed that those adhering to the teachings of Confucius could not be atheists. By stating that just as frequent and serious crimes and dissolution of morals finally leads down the road to the greatest of all crimes, atheism, so all virtue, concern with how one lives one's life, [and] pious administration of the people are clear indications of true religion'. ${ }^{134}$ Here, he warned that to call the virtuous Chinese atheists would be tantamount to conceding that 'disbelief in God could arise from reasons other than moral depravity'.135

According to Alan Charles Kors, this was exactly what those opposed to the Jesuits insisted upon claiming, which clearly brought to light the problem of how to reconcile these findings on the atheism of Confucius with accounts of his virtue. ${ }^{136}$ In his translation, Simon Foucher subsequently aimed to represent the wisdom of Confucius. He insisted that Confucian teachings and

132 Kors, Atheism in France, p. 163.

133 Couplet, Confucius Sinarum philosophus, 'Proëmialis Declaratio', pp. xxxiv-xxxviii, pp. lxix-lxxxviii.

134 Couplet, Confucius Sinarum philosophus, p. lxxxii.

135 Kors, Atheism in France, p. 164.

136 While Foucher insisted that Confucian and Christian morality conformed, other such as Simon de La Loubère conceded to the possibility of 'virtuous atheism'. His popular work reached the conclusion that 'several accounts of China assure us that their men of letters, who are the most important citizens in this country ... today have no sentiment of religion and do not believe in the existence of any God'. The Chinese followers of Confucius, whose morality was admired by De La Loubère, did not revere the true God, but merely 'the material principle of the entire world, or of its most beautiful part, which is the Sky', in Simon de La Loubère, Description du Royaume de Siam (Amsterdam: Abraham Wolfgang, 1691). 
Christian morality were in almost perfect harmony, going so far as to state that Confucius may be considered 'a kind of prophet, who foretold the coming of the Messiah.' ${ }^{137}$ Yet, in his translation, Foucher also removed much of the Jesuit and Chinese context. Consider, for example, the Jesuit rendition of the third chapter of the Lunyu, known as Ba Yi 八佾 or the incipit 'eight row dance'.

Confucius said: 'What is the use of rites, ceremonies, and external duties for someone who is dishonest, untaught in true and firm virtue? Or again, what is the use of musical harmony and tune for a dishonest man? Indeed, since all the duties and rites should flow from a virtuous soul, as from their root, if there is not such a soul, then all the rituals and duties will only be a vain pretence and fraud of humaneness. Again, a soul lacking virtue is necessarily harassed and constantly perturbed by diverse motions, and because of the disorder of the inner motions, the harmony of the musical instruments and voices will be useless.' Here again, this paragraph blames and condemns the families usurping the imperial rites. ${ }^{138}$

Foucher summarised this rather elaborate passage, which included later commentaries taken by the Jesuits from the Cheng 影 brothers Hao 程 and Yi 程, in just one sentence: 'For malicious or ignorant people, all ceremonies are useless'.139 Thierry Meynard argues that this rendition demonstrates that Foucher was more interested in presenting some purported universal core truth, by reversing centuries of Chinese tradition in collecting, interpreting, and contextualising the often very short and enigmatic statements from Confucius. ${ }^{140}$ Confucius Sinarum philosophus is essentially a presentation of a historically contextualised version of the Lunyu, a process which paradoxically is reversed by Foucher in his Lettre sur la morale. As such, Foucher was not so much interested in presenting his readers with new information about China; instead, he used Chinese culture to prove the universal validity of moral laws, just as Pieter van Hoorn attempted a similar feat with universal virtue ethics.

Foucher's concern with morality is further emphasised by his translation of the statesman and historian Wei Zheng 為政, duke of Wenzhen of Zheng of the Tang dynasty: 'Reject everything uncertain and dubious when it is about

\footnotetext{
137 'Une espèce de Prophète, qui a prédit la venuë du Messie', in Foucher, Lettre sur la morale, pp. 43-44.

138 Confucius Sinarum philosophus, secunda pars, liber tertius, 2, in Meynard, The Jesuit reading of Confucius, p. 8 o.

139 'Toutes les cérémonies sont inutiles à gens malicieux ou ignorants', in Foucher, Lettre sur la morale, p. 15.

140 Meynard, The Jesuit reading of Confucius, p. 8 o.
} 
science. ${ }^{141}$ Especially interesting is the printed note in the margins, part of the paratext, that clarifies how Foucher considered this 'the first law of the Academicians' or 'la première loy des Académiciens'. By Academicians, Foucher referred to members of the schools of Socrates and Plato, not the literati in China. Foucher proved to be a firm supporter of these academicians, writing his Dissertation sur la recherche de la vérité ou sur la philosophie académique on the very topic. ${ }^{142}$

In his earlier writings, Foucher demonstrated an opposition to the philosophy of Descartes, especially since the latter's disconnection between mind and body would (at least according to Foucher) lead to an intellectual crisis about what truth constitutes and about what the good is. ${ }^{143}$ To remedy the predicaments of this radical pessimism, 'Foucher proposed returning to the mild scepticism of the Academy. Morality should start by questioning any knowledge and then, through reason, move to affirm some moral laws which are certain. ${ }^{144}$ It is for this reason that Foucher emphasised the practical applicability of Chinese wisdom and its compatibility with Christianity in his preface: 'We can see in Confucius like a sketch or touch of Christianity, and also an abridgement of all what the philosophers recognised as the most firm in matter of morality'. ${ }^{45}$ He pursued this even further in his epilogue, writing that 'we could perhaps see Confucius as a kind of prophet who predicted the coming of Christ'. ${ }^{146}$ This sentiment echoes the principle of prisca theologia, already applied to Confucius in the writings of Athanasius Kircher and discussed in a previous chapter. Even though Foucher's statement is taken from the Jesuit translation, his reading of the same is less focused on any religious or philosophical interpretation of the teachings of Confucius. By presenting his

141 'Rejetez tout ce qui est incertain \& douteux quand il s'agit de la science', in Foucher, Lettre sur la morale, p. 15.

142 Simon Foucher, Dissertation sur la recherche de la vérité ou sur la philosophie académique [1673]. This work was never published, but was distributed by Foucher himself. No copies exist, and we know only of the work through Foucher's own references. See also Simon Foucher, Critique de la Recherche de la vérité, où l'on examine en méme temps une partie des principes de Mr Descartes (Paris: Martin Coustelier, 1675); Simon Foucher, Nouvelle dissertation sur la Recherche de la vérité (Paris: Robert de la Caille, 1679).

143 Walter R. Ott, Descartes, Malebranche, and the crisis of perception (Oxford: Oxford University Press, 2017), pp. 75-77.

144 Meynard, The Jesuit reading of Confucius, p. 81.

145 'On voit chez Confucius comme un crayon ou un ombré du Christianisme, et aussi un abrégé de tout ce que les philosophes avaient reconnu de plus solide en matière de morale', in Foucher, Lettre sur la morale, p. 2.

146 'On pourrait peut-être regarder Confucius comme une espèce de prophète qui a prédit la venue de Christ', in Foucher, Lettre sur la morale, p. 28. 
readers with easy-to-follow maxims, he showed Confucius more as a guide to morality and ethics. In the process, Foucher removed any reference to either religion or even China in general. ${ }^{147}$

How the publisher's and author's epitext was perceived by early modern readers is often hard to gauge as few commentaries or reflections are available. However, the consequences of Foucher's interference on the presentation and interpretation of China and Confucius may be gleaned from a review of his translation in the Journal des sçavans of 26 July $1688 .{ }^{148}$ This review shows how the elements beyond the text, such as authorial discourse, influenced the interpretation of the same. The review starts with a positive note on how Foucher's maxims 'cannot fail to be to the taste of those who judge things by themselves, and that the truth is always estimable from anywhere that it comes. ${ }^{149}$ Then, instead of focusing on the actual content of Lettre sur la morale, the review concentrates on the author Foucher himself, making the comparison with his previous work 'on the philosophy of the Academicians'. ${ }^{150}$ The link with the Académiciens is explicitly made: 'The author ... in another work has shown that the manner of philosophising like the Academicians is the most advantageous to religion, and the most in accordance with common-sense'. After this point, the review arrives at the conclusion that the author 'shows in it that it accords perfectly with what Confucius taught in a time and in a country where men had no other light to behave than that of nature.' ${ }^{151}$

If the review of Lettre sur la morale in the Journal des sçavans is taken as summary of how early modern readers could have read Simon Foucher's translation, its focus shows that the translation is perceived to be neither about China nor the Jesuits, nor is it truly about Confucius. The author's epitext, here associated with Academic scepticism, would frame Confucius's teachings as more of a guide to morality than anything else, where little is left of either

\footnotetext{
147 Aldridge, The dragon and the eagle, pp. 23-46.

148 Journal des sçavans (July 1688), p. 144.

149 'Les maximes qui sont rapportées dans cette lettre ne sauraient manquer d'être au goût de ceux qui jugent des choses par elles-mêmes, \& qui pensent que la vérité est toujours estimable de quelque part qu'elle vienne', in Journal des sçavans (July 1688), p. 144.

150 On Foucher's Réponse à critique de la critique de la recherche de la verité and his position as opponent of Malebrache and Leibniz, see Richard Watson, The downfall of Cartesianism, 1673-1712. A study of epistemological issues in late 17th century Cartesianism (The Hague: Martinus Nijhoff, 1966), pp. 13-28.

$15^{1}$ 'Lauteur qui dans un autre ouvrage a fait voir que la manière de philosopher des Académiciens est la plus avantageuse à la religion, \& la plus conforme au bon sens fait voir dans celui-ci qu'elle s'accorde parfaitement avec ce que Confucius a enseigné dans un temps \& dans un pays où les hommes n'avaient point d'autre lumière pour se conduire que celles de la nature', in Journal des sçavans (July 1688), p. 144.
} 
the Chinese and Jesuit religious origins or interpretation; the Journal did not even think it necessary to mention China or the Jesuits, and Confucius is only referred to only once.

The reception and interpretation of the second translation of Confucius Sinarum philosophus in French displayed a similar process of epitextual alteration. La morale de Confucius was published in 1688 by Pierre Savouret of Amsterdam. The work consisted of two parts, 'De l'antiquité de la philosophie des Chinois', and 'Recueil des ouvrages de Confucius', which, together with a preface and an epilogue, make up 130 pages. The anonymous author started by praising Confucius's morality 'which is infinitely sublime, yet still simple, reasonable, and drawn from the purest sources of natural reason'.152

In La morale de Confucius, Confucian morality was seen as the ultimate achievement of human reason, presenting a historical example of what European morality could look like if it had not been Christian. The moral teachings of Confucius 'harmonised family, social, and political life in a rational way, devoid of religious elements'.153

Surely, never had a mind devoid of the light of God's revelation appear so developed and with such force ... which is a very significant advantage

$15^{2}$ 'On peut dire que la morale de ce Philosophe est infiniment sublime, mais qu'elle est en même temps, simple, sensible, \& puisée dans les plus pures sources de la raison naturelle. Assurément, jamais la raison destituée des lumières de la rélévation divine, ná paru si développée, ni avec tant de force', in Labrune, La morale de Confucius, p. 2. While it falls outside the scope of this study, it is interesting to note that Labrune's focus on 'natural reason' foreshadows one of the major discussions on Chinese atheism of the early eighteenth century. In 1721, the German philosopher Christian Wolff held a lecture at the University of Halle praising the rationality of Confucian ethics. He argued that China was a moral society with knowledge of a divine Creator or Scripture, thus proclaiming that reason was sufficient ground for ethics. This lecture led to a scandal, constituting the first German controversy about global relations. According to Jonathan Israel, 'the conflict, which began in 1723, developed into one of the most formative cultural encounters of the eighteenth century and was, arguably, the most important of the age of Enlightenment in Central Europe and the Baltic before the French Revolution'. See Donald F. Lach, 'The sinophilism of Christian Wolff (1679-1754)',Journal of the History of Ideas, 14.4 (1953), pp. 561574; Israel, The radical Enlightenment, p. 544; Norbert Hinske, 'Wolffs Stellung in der deutschen Aufklärung', in W. Schneiders (ed.), Christian Wolff 1679-1753: Interpretationen zu seiner Philosophie und deren Wirkung (Hamburg: Felix Meiner, 1986), pp. 306-319; Daniel Purdy, 'Chinese ethics within the radical Enlightenment. Christian Wollf', in Carl Niekerk (ed.), The radical Enlightenment in German. A cultural perspective (Leiden and Boston: Brill Rodopi, 2018), pp. 112-13o.

153 Dawid Rogacz, 'The birth of Enlightenment secularism from the spirit of Confucianism', Asian philosophy (2018), e-publication. 
[of this philosophy] not only over many pagan writers, who dealt with similar material, but also over some Christian authors. ${ }^{154}$

Therefore, Christian morality presented only one of the many moralities available, amongst which the teachings of Confucius shone especially bright. The first part of the main text 'De l'antiquité de la philosophie des Chinois' focused on this natural reason, summarising the history of China and its people, followed by a short biography of Confucius. This information was taken from the preface and chronological tables of Confucius Sinarum philosophus. The second part of La morale de Confucius, 'Recueil des ouvrages de Confucius', consisted of an almost complete translation of the Latin text of many passages from Daxue and Zhongyong, including the classical text and its Chinese commentaries, as well as the notes made by the Jesuits. ${ }^{155}$ The book ends with 80 maxims, providing a selection of short statements taken from Lunyu. ${ }^{156}$ Like Foucher, the author of La morale de Confucius rejected abstract principles of morality and instead offered a moral practical guide to ethics through the teachings of Confucius.

That the publishing strategies of the French translations aimed at a more general dissemination is also mirrored in their material construction, made visible by the books' sizes, title pages, and typography. In the seventeenth century, large formats, such as Confucius Sinarum philosophus's folio, were reserved for serious works of religion and philosophy, while smaller sizes such as Foucher's and Labrune's octavo (8vo) and duodecimo (12mo) were intended for wider distribution. ${ }^{157}$ This manner of assigning the audience and genre of a work to paper size is by no means universal, yet the division was certainly predominant during the early modern period.

The material difference between the Latin and French translations is also echoed by their respective title pages. In the first centuries of the printed book, the title page was the preeminent place of the publisher's paratext. The printed cover only came along later, while the dust jacket, wrapper, slipcase, cover, or band were still the prerogative of the buyer, and thus seldom provided by the publisher. In other words: because books were sold without any covering, the title page both provided information and served as an advertisement. As such, much information was included, whereby the title page 'often constituted a

154 Labrune, La morale de Confucius, p. 4.

155 Meynard, The Jesuit reading of Confucius, pp. 82-85.

156 See Meynard, The Jesuit reading of Confucius, p. 84 n2O7 for an identification of the translated sayings with their corresponding passages.

157 Paul Needham, 'The study of paper from an archival point of view', IPH yearbook, 8 (1988), pp. 124-132. 
veritable description of the book', supplying not only the name of the author and name and address of the publisher and/or printer, but also many other things such as epigraph, mention of the dedications (with the name and title of the dedicatee), dedicatory epistles, summaries of the book's action, a definition of its subjects, a list of appendices, and often even containing an illustration or at least an ornament.

The title page of Confucius Sinarum philosophus indeed included many of these elements, making it stand in stark contrast to the more austere title pages of the translations in French. Here, we only find the most basic of information: title, place, and date of publication, the publisher's name and address, and a generic printer's ornament. Perhaps more telling is what is not mentioned. Except for the actual title, nothing indicates that the potential buyer holds in his or her hand a book about China or Chinese philosophy. Furthermore, any reference to the Jesuit origin of this information is removed, as is the name of the Catholic author. The title page does not even mention that the book is a French translation of a Latin text. These omissions clearly indicate that the publisher wished to appeal to a more general, and perhaps secularly inclined readership, not wishing to alienate any potential buyer by referring to China, the Jesuits, or the Latin and Catholic origin of content.

In analysing the bibliology of the translations, the title page and format are perhaps the most eye-catching and determinative elements of the publisher's paratext. However, there are two further features worth considering, namely the typesetting and choice of white on the page. Especially typographical choices may provide indirect commentary on the text, affecting the potential reading of the text. Again, the use of blank space is telling. The text block of Confucius Sinarum philosophus measures $14.3 \mathrm{~cm}$ by $23.2 \mathrm{~cm}$, while the page on which it is printed is $21.5 \mathrm{~cm}$ by $32.6 \mathrm{~cm}$ (which means the blank margins are 33.4 and 28.8 per cent respectively). In contrast, the margins of Lettre sur la Morale measure only $2.3 \mathrm{~cm}$ and $2.7 \mathrm{~cm}$ (or , while those of Labrune's translation are $1.8 \mathrm{~cm}$ by $3.3 \mathrm{~cm}$ (or 20.2 and 21.3 per cent). ${ }^{158}$ As stated earlier, since paper was expensive, 'excessive' use of it would add to the perception of luxury and exclusivity, and the 'grandes marges blanches de silence' on the pages of the translation in Latin do, indeed, attest to a higher quality; likewise, the smaller margins would indicate to the buyer a more cost-efficient approach.

The size, title page, and typography of Foucher's and Labrune's translation of Confucius in French communicated that these were books aimed at general readers who were more interested in general morality than in any religious or

${ }_{15}$ It is important to note that these measurements were consistent across copies, meaning that the book-block was not significantly trimmed. 
Sinological exposition. By the end of the seventeenth century, the teachings of Confucius were available in translations in Latin and a number of vernacular languages. Especially the French translations proved popular as indicated by the number of times they were reprinted. Whether this demand came about through a need for the moral and practical interpretation of Foucher and Labrune, or whether it was related to the cultural-economic laws of availability and a lower price-point, is difficult to gauge. Nevertheless, by the end of the century, the increased dissemination of images of China had not only broadened intercultural transmission, it had also deepened it. Confucius and China became part of a Europe-wide debate on politics, history, and religion. The convergence of competing claims regarding Confucian virtue and Confucian atheism had consequently truly caught the eye of a growing public of readers 'before whom the trial was continuing'. 159 At the same time, the geographical and cultural dispersion of printed works on China had shifted considerably. The Dutch Republic remained the undisputed European capital of printing and publishing; yet, during the second half of the seventeenth century, book producers began to focus more and more on an international audience, with French as its lingua franca. ${ }^{160}$ This changing perspective, in turn, influenced the presentation of China, now aimed towards an even more diversified European readership.

The early seventeenth-century European translations of Confucius involved printers and publishers from Amsterdam, Batavia, Goa, Jianchang, and Paris; missionaries from Austria, Italy, the Low Countries, and Portugal; and a variety of intermediaries from Godfried Henske's in Antwerp, Athanasius Kircher in Rome, and Simon Foucher in Paris. This varied group of people suggests that Confucius, and Chinese religion and philosophy in general, was of increasing interest to Western European readers, reaching far beyond the missionary boundaries of the Society of Jesus. The involvement of such a diverse group of translators, editors, publishers, and printers also tells us that Confucius became a point of multi-confessional concern, something that seems to be confirmed by the reception and distribution of the translations.

In 1711, Southern Netherlandish Jesuit, François Noël, made his own translation of the Four Books. Noël had joined the China mission in September 1687 after learning rudimentary Chinese in Macao. He travelled extensively

159 Histoire des Ouvrages des Savants (October 1692), pp. 94-99.

160 Simon Burrows, The French book trade in Enlightenment Europe. Enlightenment best-sellers (vol. 2, London: Bloomsbury, 2018). 
throughout the country and reported hundreds of baptised converts. ${ }^{161}$ In 1701, he was selected as procurator for the China mission in an embassy that aimed at halting the Chinese Rites Controversy. However, despite the Chinese and Jesuit testimony (the Kangxi Emperor even issued an official pronouncement) there is little evidence that Rome ever considered any of the evidence. ${ }^{162}$ After a short return to Asia, Noël settled in Prague in 1709, where he published astronomical and mathematical observations made in China and India. ${ }^{163} \mathrm{He}$ also published Latin translations of classical Chinese texts under the title, Sinensis imperii libri classici sex, or 'The six books of the Chinese Empire.'164 They contained the Great learning (Daxue), the Doctrine of the mean (Zhongyong), the Analects, as well as the collected works of Mencius (孟子), the Classic of filial piety (Xiaojing 孝經), and the Lesser learning (Xiaoxue 小學). It was the first time these last three works had been translated into a European language. Compared to Confucius Sinarum philosophus, there was 'no or very little discourse interpolated in the text', even though Noël's translation was still part of the effort to further the mission in China. In the preface, Noël admonished the reader to focus on Christian life when reading his translation of Confucius's teachings, and he hoped that the work would help in making Jesus Christ the focus of everyday life. ${ }^{165}$ As such, both works 'emerged from the same long-term Jesuit translation project' that can be traced back to Ruggieri and Ricci. ${ }^{166}$

However, even though Noël presents a more sophisticated version of Confucius, his work was not widely disseminated in Western Europe, and was even banned in the Papal States and Holy Roman Empire. In 1735, the French scholar Nicolas Fréret complained in a letter to Father Gaubil in Beijing of the unavailability of Sinensis imperii libri in Paris. ${ }^{167}$ It seems that the Chinese Rites Controversy contributed at least partly to this obscurity. Compared to the availability of Confucius Sinarum philosophus in early modern collections and as reviewed by journals, Noël's translation seems to have had little influence in Western Europe. However, as the work was published in Prague, its

161 Vladimír Liščák, 'François Noël and his Latin translations of Confucian classical books published in Prague in 1711', Anthropologia Integra, 6.2 (2015), pp. 45-52.

162 Paul A. Rule, 'François Noël, SJ, and the Chinese Rites Controversy', in Vande Walle and Golvers, The history of the relations between the Low Countries and China, pp. 137-165.

163 François Noël, Observationes mathematicae et physicae in India et China factae (Prague: Charles-Ferdinand University, 1710).

164 François Noël, Sinensis imperii libri classici sex (Prague: Charles-Ferdinand University Press, 1711); Liščák, 'François Noël (1651-1729)', pp. 45-52; Rule, 'François Noël, SJ', pp. 137-166.

165 'Utinam utrisque lapis angularis fiat christus', in Noël, Sinensis imperii, p. iv.

166 Mungello, 'Confucianism in the Enlightenment', pp. 99-128.

167 Danielle Elisseeff-Poisle, Nicolas Fréret (1688-1749). Réflexions d'un humaniste du XVIII siècle sur la Chine (Paris: Presses Universitaires, 1978), p. 53. 
distribution throughout the German lands and Eastern Europe was more substantial. Here, Noël's writings on China inspired Johann Benedikt Carpzov, Wilhelm von Leibnitz, and Christian Wolff. ${ }^{168}$ The latter even lost his position at the University of Halle due to his praise of Confucius and the assertion that the Chinese knew right from wrong, without being exposed to Christianity. ${ }^{169}$

The afterlife of Confucius Sinarum philosophus was much more momentous. A number of Dutch-made journals in French, catering to a growing public of European readers, published reviews of the book. In fact, Confucius Sinarum philosophus was the only work reviewed in every single European journal in 1687. These reviews compared Chinese and radical European doctrines, mainly in terms of their alleged monism. This soon raised the question of the extent to which praise of Confucius had become libertine and radical. In 1705, the aforementioned Gijsbrecht Cuper still waxed lyrical over the French translation by Labrune, seemingly unaware of any association with radical thinking. ${ }^{170}$ Still, for most contemporaries, the link must have been so evident that it needed little explanation. By 1708, Hendrik Smeeks, a surgeon from Zwolle, referenced Confucius as the source of inspiration for a political experiment in the unchartered Australian territories in his fantastic novel, The mighty kingdom of Krinke Kesmes. This utopian state was apparently guided by Confucius' favourite student, Krakabas. ${ }^{171}$ In Krinke Kesmes, a board of philosophers kept watch over the sovereign. In fact, the kingdom was so radical, it even housed a women's university! ${ }^{172}$ Against this fantastical 'oriental' background, the central theme of the novel is a plea for religious, political, and societal freedom of citizens in the face of worldly and ecclesiastical authorities.

By the end of the seventeenth century, missionaries of the Society of Jesus had made Confucius the central figure in Europe's interactions with China.

168 Knud Lundbaek, "The first European translations of Chinese historical and philosophical works', in Thomas Lee (ed.), China and Europe. Images and influences in sixteenth to eighteenth centuries (Hong Kong: The Chinese University Press of Hong Kong, 1991), pp. 29-44. On Christian Wolff, see note 152.

169 Shigenari Kanamori, 'Christian Wolff's speech on Confucianism. Confucius compared with Wolff', European Journal of Law and Economics, 4.2-3 (1997), pp. 299-304.

170 '[S]ijne morale gelesen, getrocken uit een grooter boeck, tot parijs ... gedruckt', Gijsbert Cuper to Nicolaas Witsen, 3 November 1705, Allard Pierson Amsterdam, ubA Be 36, fol. gor-9iv.

171 '[D]en goeden Philosooph Krakabas, deesen was een lieveling en Discipel van den grooten Wijsgeer Confucius in China', in Hendrik Smeeks, Beschryvinge van het magtig Koningryk Krinke Kesmes (Amsterdam: Nicolaas ten Hoorn, 1708), pp. 242-243.

172 A. Agnes Sneller, 'Utopia of een vrouwenuniversiteit omstreeks 170o', Literatuur, 5 (1988), pp. 141-148. 
Through their policy of accommodation, the Chinese sage became a philosopher who used rational means to achieve a moral life, and a saint who had prepared the way for Jesus Christ. The Jesuits rejected Buddhism and Taoism as idolatrous, while Confucianism was regarded as a system of moral teaching compatible with Christianity. As such, Confucian rites, such as ancestor veneration, were regarded as civil and cultural functions, rather than religious rites. By accommodating the Confucian teachings, the Jesuits could centre their work on the contacts with the Chinese Confucian literati.

The Jesuits were firmly rooted on Chinese soil, and the eyewitness accounts they sent back to Europe were readily adopted by Dutch authors, editors, translators, printers, publishers, and printmakers. Guided by carefully considered publishing strategies and economic rules to cultural consumption, these Dutch intermediaries subsequently constructed their own Chinese narratives, which further shaped and disseminated images of Confucius and the Middle Kingdom throughout Europe. Furthermore, because of the exceptional quality of Dutch print and their excellent networks of distribution, this dissemination was wide and defining.

In this period, one of the most influential books on China was Athanasius Kircher's China illustrata of 1667. Together with his Dutch publisher, this German Jesuit presented a representation of China and its religion and philosophy that could be traced all the way back to ancient Egypt. Confucianism, as such, was a historical continuation of Egypt's prisca theologia, in which both Egyptian hieroglyphs and Chinese characters contained an occult Hermetic philosophy of pre-Mosaic origins. However, by comparing Confucius to Thoth-Hermes Trismegistus, Kircher undermined the Jesuit strategy of accommodation by presenting the Chinese sage as a kind of demi-god. Transtextual interventions by subsequent editors further exacerbated this problem.

The Jesuit policy of accommodation had long proved contentious and, to defend their approach to their superiors and the European public in general, they published a Latin translation and interpretation of the main works of Confucius in 1687. Their primary aim was to Christianise Confucius and Chinese civilisation for a learned European audience; this aim was helped along by the form and content of publication. Even though Confucius Sinarum philosophus was a Jesuit venture, Dutch involvement has demonstrated that the representation of Confucius had become a varied European project. The Jesuits' global intellectual network helped them explain their policy of accommodation; nonetheless, they needed Dutch logistical support to facilitate the effective circulation of their message. In turn, Dutch authors, printers, and publishers would benefit from this collaboration as Jesuit involvement helped 
them expand and broaden their selection of books on China. Indeed, throughout the seventeenth century, the Dutch Republic remained Europe's primary entrepôt for printed works on the Middle Kingdom.

While the Jesuits had been busy translating Confucius from the late sixteenth century onwards, the first vernacular translation of the Four Books was, in fact, written by Dutchman Pieter van Hoorn and printed in Batavia in 1675 . He had turned to Confucius for instructions on how to live a virtuous life, even praising the Chinese sage as superior to European philosophers. Van Hoorn probably used a Jesuit translation in manuscript for his source, yet his edition may have been influenced by contact with the sizeable community of Chinese in Batavia. The Van Hoorn family archive (now held in The Hague) attested to extensive interactions between Pieter, his son Johan, their translator Johannes Melman, and various Chinese interlocutors.

The influence of both the Jesuit translation in Latin and the Van Hoorn translation in Dutch emerged more through the circulation of intellectual content, and less by any physical distribution of either work. However, the economic and intellectual potential of Confucius was soon realised and two partial French translations of Confucius Sinarum philosophus were published within the year. These aimed at the general, and perhaps less affluent, public, who now could discover Confucius for themselves through the translations by Simon Foucher and Jean de Labrune. Both translations demonstrate various processes of transtextual alteration in form and content. By the time we come to these translations, however, little is left of either their Chinese origins or the Jesuit interpretations; in adapting the French translations to a general audience more interested in morality, both editors and publishers transformed the teachings of Confucius into something decidedly more secular.

The publication of Confucius Sinarum philosophus in 1687 would prove to be only the prelude to decades of discussion and polarisation on topics such as Chinese religion and philosophy, the Jesuit origin of information, and their policy of accommodation. The controversy embroiled several popes (among them Clement XI and Clement XIV), the Qing Emperor Kangxi, the Sorbonne in Paris, and various leading European universities. The Chinese rites had long been debated behind the closed doors of offices of the Holy See, yet, by the end of the century, the controversy became a more public dispute. This shift was in part facilitated by Dutch printing presses, which turned out an increasing amount of printed works, including books, learned journals, pamphlets, and newspapers, on the subject. 